Research article

Open Access

\title{
Induction by transforming growth factor- $\beta 1$ of epithelial to mesenchymal transition is a rare event in vitro
}

\author{
Kimberly A Brown ${ }^{1,2}$, Mary E Aakre ${ }^{1,2}$, Agnieska E Gorska ${ }^{1,2}$, James O Price ${ }^{1,3,4}$, Sakina E Eltom ${ }^{5}$, \\ Jennifer A Pietenpol ${ }^{1,6}$ and Harold L Moses ${ }^{1,2}$
}

\author{
${ }^{1}$ Vanderbilt-Ingram Cancer Center, Vanderbilt University Medical Center, Nashville, Tennessee, USA \\ ${ }^{2}$ Department of Cancer Biology, Vanderbilt University Medical Center, Nashville, Tennessee, USA \\ ${ }^{3}$ Department of Pathology, Vanderbilt University Medical Center, Nashville, Tennessee, USA \\ ${ }^{4}$ Veterans Affairs Medical Center, Vanderbilt University Medical Center, Nashville, Tennessee, USA \\ ${ }^{5}$ Department of Pharmacology, Meharry Medical College, Nashville, Tennessee, USA \\ ${ }^{6}$ Department of Biochemistry, Vanderbilt University Medical Center, Nashville, Tennessee, USA \\ Corresponding author: Harold L Moses (e-mail: hal.moses@vanderbilt.edu)
}

Received: 21 May 2003 Revisions requested: 20 Jun 2003 Revisions received: 10 Feb 2004 Accepted: 20 Feb 2004 Published: 17 Mar 2004

Breast Cancer Res 2004, 6:R215-R231 (DOI 10.1186/bcr778)

(C) 2004 Brown et al., licensee BioMed Central Ltd. This is an Open Access article: verbatim copying and redistribution of this article are permitted in all media for any purpose, provided this notice is preserved along with the article's original URL.

\begin{abstract}
Introduction: Transforming growth factor (TGF)- $\beta 1$ is proposed to inhibit the growth of epithelial cells in early tumorigenesis, and to promote tumor cell motility and invasion in the later stages of carcinogenesis through the induction of an epithelial to mesenchymal transition (EMT). EMT is a multistep process that is characterized by changes in cell morphology and dissociation of cell-cell contacts. Although there is growing interest in TGF- $\beta 1$-mediated EMT, the phenotype is limited to only a few murine cell lines and mouse models.
\end{abstract}

Methods: To identify alternative cell systems in which to study TGF- $\beta 1$-induced EMT, 18 human and mouse established cell lines and cultures of two human primary epithelial cell types were screened for TGF- $\beta 1$-induced EMT by analysis of cell morphology, and localization of zonula occludens-1, E-cadherin, and F-actin. Sensitivity to TGF- $\beta 1$ was also determined by $\left[{ }^{3} \mathrm{H}\right]$ thymidine incorporation, flow cytometry, phosphorylation of Smad2, and total levels of Smad2 and Smad3 in these cell lines and in six additional cancer cell lines.

Results: TGF- $\beta 1$ inhibited the growth of most nontransformed cells screened, but many of the cancer cell lines were insensitive to the growth inhibitory effects of TGF- $\beta 1$. In contrast, TGF- $\beta 1$ induced Smad2 phosphorylation in the majority of cell lines, including cell lines resistant to TGF- $\beta 1$ mediated cell cycle arrest. Of the cell lines screened only two underwent TGF- $\beta 1$-induced EMT.

Conclusion: The results presented herein show that, although many cancer cell lines have lost sensitivity to the growth inhibitory effect of TGF- $\beta 1$, most show evidence of TGF- $\beta 1$ signal transduction, but only a few cell lines undergo TGF- $\beta 1$ mediated EMT.

Keywords: E-cadherin, epithelial to mesenchymal transition, Smad, TGF- $\beta 1$, ZO-1

\section{Introduction}

Transforming growth factor (TGF)- $\beta 1$ is a cytokine that is involved in immune suppression, angiogenesis, apoptosis, cell growth, and epithelial to mesenchymal transitions (EMTs) during carcinogenesis [1-7]. TGF- $\beta 1$ signals through the TGF- $\beta$ type I (T $\beta$ RI) and TGF- $\beta$ type II (T $\beta$ RII) transmembrane serine/threonine protein kinase receptors.
When TGF- $\beta 1$ binds T $\beta R I I, T \beta R I$ is recruited to T $\beta R I I$, and $T \beta R$ Il phosphorylates and activates the kinase activity of $T \beta R I$. Activated T $\beta R I$ interacts with and phosphorylates a number of proteins, thereby activating many downstream signaling pathways, including the Smad (Sma/Mothers Against Decapentaplegic) pathway. The Smad signaling cascade is initiated by the phosphorylation of Smad2 or

DMEM = Dulbecco's modified Eagle's medium; EGF = epidermal growth factor; EMT = epithelial to mesenchymal transition; FBS = fetal bovine serum; HEK = human epidermal keratinocytes; $\mathrm{HMEC}=$ human mammary epithelial cell; $\mathrm{KC}=$ mouse keratinocytes transformed with $\mathrm{K}$-ras; $\mathrm{MEM}=$ minimal essential medium; MK = mouse keratinocyte; PBS = phosphate buffered saline; Smad = Sma/Mothers Against Decapentaplegic; T $\beta R I=$ TGF- $\beta$ type I receptor; T $\beta$ RII $=$ TGF- $\beta$ type II receptor; TGF $=$ transforming growth factor; TTBS $=$ Tris buffered saline with Tween-20; ZO = zonula occludens. 
Smad3 by T $\beta$ RI. Phosphorylated Smad2 and Smad3 associate with Smad4 and are translocated to the nucleus, where they modulate transcription of many genes [8-13].

In early tumorigenesis TGF- $\beta 1$ inhibits the growth of epithelial cells, and insensitivity to this growth inhibitory effect is associated with tumor progression $[5,6]$. Transgenic mice expressing a dominant negative TRRII in the epidermis and mammary glands exhibit accelerated tumor formation and malignant conversion [14,15]. Resistance to the antiproliferative effects of TGF- $\beta 1$ is observed in head and neck squamous cell carcinomas [16-18], lung cancer [19], gastric cancer [20-22], colon cancer [22-25], pancreatic cancer [26], ovarian cancer $[27,28]$, and in some recurrent breast cancers $[29,30]$. This loss of sensitivity to TGF- $\beta 1$ is due to mutations in or transcriptional repression of the genes that encode T $\beta R \mathrm{R}$ and/or T $\beta$ RIl. Mutations in the genes encoding Smad2 (MADH2) and Smad4 (MADH4) also contribute to the insensitivity to TGF- $\beta 1$ in many lung [31], pancreatic [32], and colorectal $[33,34]$ carcinomas.

In contrast to the growth inhibitory effects of TGF- $\beta 1$ in the early stages of carcinogenesis, TGF- $\beta 1$ can also act as a promoter of tumor cell invasion and metastasis in the later stages of tumorigenesis $[5,6]$. Increased production of TGF- $\beta 1$ is observed in epidermal [35], gastric [36], renal [37], breast [38-41], and prostate carcinomas [42] when compared with normal tissues. In mice with polyomavirus middle $T$ antigen expression targeted to the mammary gland, blockade of TGF- $\beta 1$ by administration of Fc:T $\beta R$ Il results in increased apoptosis in primary tumors and reduced tumor cell motility, intravasation, and metastasis [43]. Chronic exposure of mouse epidermal cells to TGF- $\beta 1$ results in loss of TGF- $\beta 1$-mediated growth inhibition and marked changes in cell morphology, downregulation of E-cadherin and cytokeratins, upregulation of vimentin, and formation of spindle cell carcinomas in mice $[44,45]$. Further studies show that carcinomas with excess TGF- $\beta 1$ production are more motile and invasive, and exhibit increased tumor cell metastasis in athymic mice [36,40,45-51].

One mechanism by which TGF- $\beta 1$ can promote tumor cell motility and invasion is through the induction of EMT [52]. EMT is a complex process that involves changes in cell morphology and dissociation of cell-cell contacts [53,54]. Cells undergoing EMT change from a cobblestone-like appearance to an elongated, mesenchymal phenotype. Accompanying this morphologic change is the delocalization of adherens and tight junctional proteins from the cell-cell junctions, and remodeling of the actin cytoskeleton $[53,54]$. Characteristics associated with EMT, such as the dissociation of cell-cell and cell-extracellular logy, and rearrangement of the cytoskeleton, can facilitate cell migration and invasion [55-57].

Although TGF- $\beta 1$ is thought to play a key role in EMT in vivo, the frequency of TGF- $\beta 1$-induced EMT in vitro is not known. To identify alternative cell systems in which to study TGF- $\beta 1$-mediated EMT, we screened primary cultures of two human epithelial cell types and 18 established mouse and human cell lines for TGF- $\beta 1$ responsiveness. We also included six additional cancer cell lines as a comparison for TGF- $\beta 1$ responsiveness. We found that many of the cell strains displayed morphological changes and exhibited actin stress fiber responses to TGF- $\beta 1$. However, only in the NMuMG and MCT cells were those changes accompanied by a loss of E-cadherin and zonula occludens (ZO)- 1 at cell-cell junctions after 48 hours of TGF- $\beta 1$ treatment. Whereas all of the nontransformed cells were growth inhibited by TGF- $\beta 1$, many of the cancer cell lines were insensitive to the growth inhibitory effects of TGF- $\beta 1$. The TGF- $\beta 1$-mediated growth inhibition was accompanied by an increase in phosphorylated Smad2 protein levels, but this was not unique to growth inhibited cells because changes in Smad2 phosphorylation occurred in a majority of cells after TGF- $\beta 1$ treatment. In addition, prolonged TGF- $\beta 1$ treatment induced a decrease in total Smad2 and/or total Smad3 in some cell lines. Our findings show that, although many cancer cells lost sensitivity to the growth inhibitory effect of TGF- $\beta 1$, only two murine cell lines underwent TGF- $\beta 1$-mediated EMT and these cells retain growth inhibitory response to TGF- $\beta 1$.

\section{Methods}

\section{Cell lines and culture conditions}

A549, BT549, DU145, H1299, HBL100, MCF10A, MCF7, MDA-MB-231, MDA-MB-361, MDA-MB-435S, MDA-MB-436, MDA-MB-468, NMuMG, and 4T1 cells were purchased from American Type Culture Collection (Rockville, MD, USA). Primary human epidermal keratinocytes (HEKs) from human infant foreskin were obtained from the Vanderbilt University Skin Disease Research Center. Primary human mammary epithelial cells (HMECs) from two females (\#1012 and \#1016) were isolated and provided by S Eltom (Meharry Medical College). Mouse keratinocyte (MK) cells were provided by $B$ Weissman (University of North Carolina, Chapel Hill, NC, USA). $\mathrm{EpH} 4$ cells were provided by $\mathrm{C}$ Arteaga (Vanderbilt University). KC (mouse keratinocytes transformed with $\mathrm{K}$-ras) cells were derived from BALB/MK cells by Kirsten murine sarcoma virus transformation, as described previously [58]. HaCaT cells were provided by P Boukamp (Deutsches Krebsforschungszentrum, Heidelberg, Germany). MCT cells were provided by $E$ Neilson (Vanderbilt University). Panc-1 tumor cells were provided by $L$ Matrisian (Vanderbilt University). Colo357 tumor cells were provided by M Korc (University of California, Irvine, CA, USA). 
SCC012 and SCC028 cells were provided by D Sidransky (Johns Hopkins University, Baltimore, MD, USA). Finally, UNC10 cells were provided by W Yarbrough (Vanderbilt University).

A549, Colo357, DU145, EpH4, H1299, HaCaT, HBL100, MCT, Panc-1, and 4T1 cells were maintained in Dulbecco's modified Eagle's medium (DMEM)/high-glucose medium (HyClone, Logan, UT, USA) supplemented with 10\% fetal bovine serum (FBS). BT549 cells were maintained in RPMI-1640 medium (HyClone) supplemented with 10\% FBS and $10 \mu \mathrm{g} / \mathrm{ml}$ insulin. NMuMG cells were maintained in DMEM/high-glucose medium supplemented with $10 \%$ FBS and $10 \mu \mathrm{g} / \mathrm{ml}$ insulin. HMEC-1016 and HMEC-1012 were grown in DMEM:F12 medium (1:1) (GibCoBRL, Grand Island, NY, USA) supplemented with $1 \%$ FBS, $10 \mu \mathrm{g} / \mathrm{ml}$ ascorbic acid, $2 \mathrm{nmol} / \mathrm{l} \beta$-estradiol, $35 \mu \mathrm{g} / \mathrm{ml}$ bovine pituitary extract, $1 \mathrm{ng} / \mathrm{ml}$ cholera toxin, $12.5 \mathrm{ng} / \mathrm{ml}$ epidermal growth factor (EGF), $0.1 \mathrm{mmol} / \mathrm{l}$ ethanolamine, $0.1 \mathrm{mmol} / \mathrm{l}$ phospho-ethanolamine, $1 \mu \mathrm{g} / \mathrm{ml}$ hydrocortisone, $1 \mu \mathrm{g} / \mathrm{ml}$ insulin, $0.2 \mathrm{mmol} / / \mathrm{l}$-glutamine, $10 \mathrm{nmol} / / \mathrm{T}$, $10 \mu \mathrm{g} / \mathrm{ml}$ transferrin, and $15 \mathrm{nmol} / \mathrm{l}$ sodium selenite.

HEKs were maintained in EpiLife medium supplemented with human keratinocyte growth supplement (S-001-5) and $0.06 \mathrm{~mol} / / \mathrm{CaCl}_{2}$ (Cascade Biologics, Portland, OR, USA). MCF-7 cells were maintained in minimal essential medium (MEM; GibCoBRL) supplemented with 10\% FBS, $10 \mu \mathrm{g} / \mathrm{ml}$ insulin, $1 \%$ nonessential amino acids, and $22 \mu \mathrm{g} / \mathrm{ml}$ sodium pyruvate. MCF10A cells were cultured in (1:1) DMEM:F12 medium (Hyclone) supplemented with $5 \%$ horse serum, $100 \mathrm{ng} / \mathrm{ml}$ cholera toxin, $20 \mathrm{ng} / \mathrm{ml}$ EGF, $500 \mathrm{ng} / \mathrm{ml}$ hydrocortisone, and $10 \mu \mathrm{g} / \mathrm{ml}$ insulin. MDAMB-231, $-361,-435 S$, and -436 cells were maintained in McCoy's 5A medium (HyClone) supplemented with 10\% FBS. MDA-MB-468 cells were grown in DMEM/highglucose:McCoy's 5A medium (1:1) supplemented with $10 \%$ FBS. MK and KC cells were maintained in DMEM/high-glucose medium supplemented with $8 \%$ dialyzed FBS, $5 \mu \mathrm{g} / \mathrm{ml}$ calcium, and $4 \mathrm{ng} / \mathrm{ml}$ EGF. SCC0 12 and SCC028 cells were maintained in RPMI-1640 medium supplemented with 10\% FBS, 1\% insulintransferrin-selenium A, 1\% L-glutamine, and 1\% nonessential amino acids. UNC10 cells were grown in DMEM/ high-glucose medium supplemented with 10\% FBS, 1\% insulin-transferrin-selenium A, 1\% L-glutamine, and 1\% nonessential amino acids.

All cell lines were maintained at $37^{\circ} \mathrm{C}$ in $5 \% \mathrm{CO}_{2}$, except for the NMuMG, MK, and KC cells, which were grown in $7 \% \mathrm{CO}_{2}$.

\section{Antibodies and other reagents}

TGF- $\beta 1$ was from R\&D Systems (Minneapolis, MN, USA). Antibodies to Smad2/3 (mouse) and E-cadherin (mouse) were from BD Transduction Laboratories (San Diego, CA,
USA); antibodies to phosphorylated (Ser 465/467) Smad2 (rabbit lot \#21034 and \#24432) were from Upstate Biotechnology (Lake Placid, NY, USA); and antibodies to ZO-1 (rat) were from Chemicon International (Temecula, CA, USA). Smad3 (rabbit) and ZO-1 (rabbit ZR-1) antibodies were obtained from Zymed Laboratories Inc. (San Francisco, CA, USA). Anti-actin (rabbit) antibodies and streptavidin-Cy3 conjugate were obtained from Sigma (St. Louis, MO, USA). Rabbit anti-goat, goat anti-mouse, and goat anti-rat biotinylated antibodies were obtained from Vector Laboratories Inc. (Burlingame, CA, USA).

\section{$\left[{ }^{3} \mathrm{H}\right]$ Thymidine incorporation assays}

Subconfluent cells were treated with TGF- $\beta 1(5 \mathrm{ng} / \mathrm{ml})$ for 46 hours in 12-well plates and pulsed for 2 hours with $4 \mu \mathrm{Ci} /$ well $\left[{ }^{3} \mathrm{H}\right]$ thymidine (Perkin Elmer Life Sciences, Boston, MA, USA). Cells were fixed with $1 \mathrm{ml} 10 \%$ trichloroacetic acid for $30 \mathrm{~min}$ at $25^{\circ} \mathrm{C}$, followed by two washes with $10 \%$ trichloroacetic acid. DNA was solubilized by incubation in $600 \mu \mathrm{l} 0.2 \mathrm{~N} \mathrm{NaOH}$ for $30 \mathrm{~min}$, and radioactivity was counted using $200 \mu \mathrm{l}$ solubilized DNA in $4 \mathrm{ml}$ scintillation fluid.

\section{Flow cytometry analyses}

Subconfluent cells were treated with TGF- $\beta 1(5 \mathrm{ng} / \mathrm{ml})$ for 48 hours and approximately $10^{6}$ cells were incubated in propidium iodide solution $(50 \mu \mathrm{g} / \mathrm{ml}$ propidium iodide (Sigma), $5 \mu \mathrm{g} / \mathrm{ml}$ RNase A, $0.1 \%$ Triton X-100, and $1 \mu \mathrm{g} / \mathrm{ml}$ sodium citrate) for $5-10 \mathrm{~min}$. Stained cells were analyzed using a FACS Caliber (Becton-Dickinson, San Jose, CA, USA) and the data stored as listmode files. DNA cell cycle histograms were analyzed and modeled using ModFit and WinList software (Verity Software House, Topsham, ME, USA). Fifteen thousand events were analyzed for each sample.

\section{Cell lysis and immunoblot analyses}

After 2 hours or 48 hours of treatment with TGF- $\beta 1$ $(5 \mathrm{ng} / \mathrm{ml})$, cells were lysed in protein lysis buffer (50 mmol/l Tris pH 7.5, $100 \mathrm{mmol} / \mathrm{l} \mathrm{NaCl}, 0.5 \% \mathrm{NP}-40$, $50 \mu \mathrm{g} / \mathrm{ml}$ PMSF, $\left.4 \mathrm{mmol} / \mathrm{l} \quad \mathrm{NaF}, 0.1 \mathrm{mmol} / \mathrm{l} \quad \mathrm{Na}_{3} \mathrm{VO}_{4}\right)$ supplemented with protease inhibitors, and protein concentrations in cell lysates were determined using the Bradford method. Protein extracts $(100 \mu \mathrm{g} / \mathrm{lane})$ were separated by $12 \%$ SDS-PAGE and transferred to polyvinylidene fluoride membranes (Immobilon-P; Millipore, Bedford, MA, USA). Membranes were blocked in $5 \%$ nonfat dry milk in Tris buffered saline with Tween-20 (TTBS; $150 \mathrm{mmol} / \mathrm{l} \mathrm{NaCl}, 100 \mathrm{mmol} / \mathrm{l}$ Tris, $\mathrm{pH} \mathrm{7.5,0.1 \%}$ Tween-20) for 2 hours at $25^{\circ} \mathrm{C}$. Membranes to be incubated in phosphorylated Smad2 antibodies lot \#24432 were not blocked in milk. Membranes were incubated with primary antibodies diluted in TTBS buffer plus 1\% milk (rabbit Smad2 1:1000, phosphorylated Smad2 1:1000 lot \#21034 or 1:200 lot \#24432, rabbit Smad3 1:300, actin 1:500) for 1 hour or overnight at $4^{\circ} \mathrm{C}$ 
for phosphorylated Smad2 lot \#24432, washed for $20 \mathrm{~min}$ in TTBS buffer, and incubated in secondary antibodies diluted in TTBS buffer plus 1\% milk (1:10000) for 1 hour at $25^{\circ} \mathrm{C}$. Membranes were washed two times in TTBS buffer ( $45 \mathrm{~min} /$ wash) and immunoreactive bands were visualized by enhanced chemiluminescence.

\section{Immunofluorescence microscopy}

Subconfluent cells, grown on $22 \mathrm{~mm}^{2}$ glass cover slips (VWR Scientific, Atlanta, GA, USA), were treated for 48 hours or 6 days with $5 \mathrm{ng} / \mathrm{ml}$ TGF- $\beta 1$. After treatment, cells were washed once with phosphate buffered saline (PBS) and fixed with 100\% cold methanol (for rat ZO-1 and E-cadherin antibody use), 4\% paraformaldehyde/PBS (for F-actin staining), or $1 \%$ paraformaldehyde/PBS (for rabbit ZO-1 antibody use) for $20 \mathrm{~min}$ at $25^{\circ} \mathrm{C}$. Cells were washed four times with PBS, permeabilized by incubation with $0.2 \%$ Triton $\mathrm{X}-100$ (in PBS) for $10 \mathrm{~min}$ at $25^{\circ} \mathrm{C}$, and then washed two more times with PBS. For ZO-1 and E-cadherin staining, nonspecific binding sites were blocked by cellular incubation for 2 hours with 5\% serum (goat serum for rabbit ZO-1 and E-cadherin antibody use and rabbit serum for rat ZO-1 antibody use) in PBS, incubated in primary antibodies diluted in $5 \%$ serum/PBS (rat ZO-1 1:1000, rabbit ZO-1 1:100, and E-cadherin $1: 2500$ ) for 1 hour at $25^{\circ} \mathrm{C}$, followed by four washes with PBS. Cells were incubated in appropriate biotinylated secondary antibodies diluted in 5\% serum/PBS $(1: 250)$ for 1 hour at $25^{\circ} \mathrm{C}$, washed four times with PBS, and incubated in streptavidin-conjugated Cy3 diluted in 5\% serum/PBS $(1: 1000)$ for 1 hour at $25^{\circ} \mathrm{C}$. Cells were washed four times with PBS and nuclei were counterstained by incubation with $0.1 \mu \mathrm{g} / \mathrm{ml}$ Hoechst (33258) for $15 \mathrm{~min}$ at $25^{\circ} \mathrm{C}$. For F-actin staining, cells were incubated in Texas Red-X phalloidin (Molecular Probes Inc., Eugene, OR, USA) diluted in PBS $(1: 200)$ for 30 min, washed with PBS three times, and were counterstained with Hoechst as described above.

After Hoechst staining, cells were washed three times with PBS and cover slips were mounted onto $25 \times 75 \mathrm{~mm}$ microslides (Fisher Scientific, Pittsburgh, PA, USA) using AquaPolyMount (Polysciences, Warrington, PA, USA). Phase contrast images were captured using the Zeiss Epifluorescence inverted microscope and Zeiss AxioCam digital camera (Carl Zeiss, Jena, Germany). Fluorescent images were captured using the Zeiss Axiophot upright microscope (Carl Zeiss) and the Princeton Instruments cooled CCD digital camera (Princeton Scientific Instruments, Inc., Monmouth Junction, NJ, USA).

\section{Results}

Transforming growth factor- $\beta 1$ induced epithelial to mesenchymal transition in NMUMG and MCT cells

To determine the frequency of TGF- $\beta 1$-mediated EMT in from human and mouse epidermis, mammary gland, lung, pancreas, kidney, and prostate (Table 1). In addition to the established cell lines, primary cultures of human epidermal keratinocytes (HEKs) and human mammary gland epithelial cells (HMEC-1012 and HMEC-1016) were also screened (Table 1). In the present study, EMT was defined as acquisition of a spindle-shaped morphology, loss of ZO-1 and E-cadherin from cell-cell junctions, and formation of actin stress fibers after TGF- $\beta 1$ treatment. Using phase contrast and immunofluorescence microscopy, we determined that only two cell lines underwent EMT. After 48 hours of TGF- $\beta 1$ treatment, the NMuMG and MCT cells became elongated (Fig. 1a,e,i,m), lost E-cadherin (Fig. 1b,f,j,n) and ZO-1 (Fig. 1c,g,k,o) staining at cell-cell junctions, and developed actin stress fibers (Fig. 1d,h,l,p).

The primary cultures of breast epithelial cells (HMEC-1012 and HMEC-1016) acquired a spindle-shaped morphology, whereas the primary cultures of HEKs did not change cell morphology after 48 hours of TGF- $\beta 1$ treatment (Fig. 2a,e,i,m; and data not shown). In addition, the HMECs and HEKs developed actin stress fibers after treatment (Fig. 2d,h,l,p; and data not shown). However, the HMECs and HEKs did not lose junctional E-cadherin staining (Fig. $2 \mathrm{~b}, \mathrm{f}, \mathrm{j}, \mathrm{n}$; and data not shown) after TGF- $\beta 1$ treatment for 48 hours. These cells also had little or no ZO-1 localized to their cell-cell junctions (Fig. 2c,g,k,o; and data not shown).

The human breast epithelial cell line MCF10A did not become elongated (Fig. 3a,e) or lose junctional E-cadherin or ZO-1 staining (Fig. $3 b, f, c, g$ ) in response to 48 hours of TGF- $\beta 1$ treatment. After treatment, these cells exhibited some actin stress fiber formation (Fig. 3d,h). However, the MCF10A cells acquired a spindle-shaped morphology (Fig. 3i,m) and actin stress fibers (Fig. 3l,p), and lost much of the junctional E-cadherin and ZO-1 (Fig. 3j,n,k,o) after TGF- $\beta 1$ treatment for 6 days. The HaCaT, UNC10, A549, Colo357, DU145, MK, KC, and 4T1 cells also exhibited an actin stress fiber response to TGF- $\beta 1$, without delocalization of E-cadherin or ZO-1 from the cell-cell junctions, similar to the MCF10A cells after 48 hours of TGF- $\beta 1$ treatment (Fig. 4b,f,r,v,c,g,s,w,d,h,t,x; and data not shown).

Other cell lines screened did not exhibit any changes in cell morphology or relocalization of E-cadherin, ZO-1, or actin after treatment with TGF- $\beta 1$. These cell lines included SCC012, SCC028, HBL100, BT549, MCF7, MDA-MB231, MDA-MB-361, MDA-MB-435S, MDA-MB-436, MDAMB-468, H1299, Panc-1, and EpH4 cells (Fig. 4i-p; and data not shown). A summary of the TGF- $\beta 1$-induced cellular response of the cell strains that exhibited acquisition of a spindle-shaped morphology, loss of junctional E-cadherin or ZO-1, or formation of actin stress fibers is presented in Table 2. 
Table 1

Tissue origin, description, and morphology of cell strains used

\begin{tabular}{|c|c|c|c|}
\hline Tissue origin & Cell strain & Description & Cell morphology \\
\hline \multicolumn{4}{|l|}{ Human } \\
\hline \multirow[t]{5}{*}{ Epidermoid } & HEK & Primary epidermal keratinocyte & Epithelial \\
\hline & $\mathrm{HaCaT}$ & Keratinocyte (abdominal skin) & Epithelial \\
\hline & SCC012 & Head and neck squamous cell carcinoma & Epithelial \\
\hline & SCC028 & Head and neck squamous cell carcinoma & Spindle \\
\hline & UNC10 & Head and neck squamous cell carcinoma & Spindle \\
\hline \multirow[t]{10}{*}{ Breast } & $\mathrm{HMEC}^{\mathrm{a}}$ & Primary breast epithelium & Epithelial \\
\hline & HBL100 & Breast epithelium & Epithelial \\
\hline & MCF10A & Breast epithelium & Epithelial \\
\hline & BT549 & Breast ductal carcinoma & Spindle \\
\hline & MCF7 & Pleural metastasis of breast adenocarcinoma & Epithelial \\
\hline & MDA-MB-231 & Pleural metastasis of breast adenocarcinoma & Spindle \\
\hline & MDA-MB-361 & Brain metastasis of breast adenocarcinoma & Epithelial \\
\hline & MDA-MB-435S & Pleural metastasis of breast adenocarcinoma & Spindle \\
\hline & MDA-MB-436 & Pleural metastasis of breast adenocarcinoma & Spindle \\
\hline & MDA-MB-468 & Pleural metastasis of breast adenocarcinoma & Epithelial \\
\hline \multirow[t]{2}{*}{ Lung } & A549 & Non-small-cell lung carcinoma & Epithelial \\
\hline & H1299 & Lymph node metastasis of non-small-cell lung carcinoma & Epithelial \\
\hline \multirow[t]{2}{*}{ Pancreas } & Colo357 & Pancreatic carcinoma & Epithelial \\
\hline & Panc-1 & Pancreatic ductal carcinoma & Epithelial \\
\hline Prostate & DU145 & Brain metastasis of prostate adenocarcinoma & Epithelial \\
\hline \multicolumn{4}{|l|}{ Mouse } \\
\hline \multirow[t]{2}{*}{ Epidermoid } & MK & Epidermal keratinocytes & Epithelial \\
\hline & $\mathrm{KC}$ & K-Ras transformed epidermal keratinocytes & Epithelial \\
\hline \multirow[t]{3}{*}{ Mammary gland } & NMuMG & Mammary gland epithelium & Epithelial \\
\hline & $\mathrm{EpH} 4$ & Mammary gland epithelium & Epithelial \\
\hline & $4 \mathrm{~T} 1$ & Mammary tumor & Epithelial \\
\hline Kidney & MCT & Proximal tubular epithelial & Epithelial \\
\hline
\end{tabular}

aHuman mammary epithelial cells (HMECs) from patients \#1012 and \#1016. HEK, primary human epidermal keratinocytes; MK, mouse keratinocytes.

\section{Transforming growth factor- $\beta 1$-induced inhibition of S-phase}

Previous studies analyzing TGF- $\beta 1$ induction of EMT have emphasized the stages in which TGF- $\beta 1$ acts as a promoter of carcinogenesis. It is proposed that cells first lose sensitivity to the growth inhibitory effects of TGF- $\beta 1$, before TGF- $\beta 1$ can promote EMT and cancer progression [59]. Therefore, we examined whether there was a correlation between TGF- $\beta 1$-mediated EMT and loss of sensitivity to the growth inhibitory effects of TGF- $\beta 1$ by examining $\left[{ }^{3} \mathrm{H}\right]$ thymidine incorporation and flow cytometry.
In $\left[{ }^{3} \mathrm{H}\right]$ thymidine incorporation experiments, it was observed that $41 \%$ of the cell strains screened had a $0-25 \%$ reduction in $\left[{ }^{3} \mathrm{H}\right]$ thymidine incorporation (or $75 \%$ of the control) after 48 hours of TGF- $\beta 1$ treatment. These cells included SCC028, UNC10, HBL100, MDA-MB-361, MDA-MB-435S, MDA-MB-436, MDA-MB-468, H1299, Colo357, Panc-1, and 4T1 (Fig. 5 and Table 3). Similarly, $37 \%$ of the cell strains screened had a $25-75 \%$ reduction in $\left[{ }^{3} \mathrm{H}\right]$ thymidine incorporation (or $75-25 \%$ of the control) after 48 hours of TGF- $\beta 1$ treatment. These cells included HaCaT, SCC012, HMEC (1016), MCF10A, BT549, MCF7, 
Figure 1

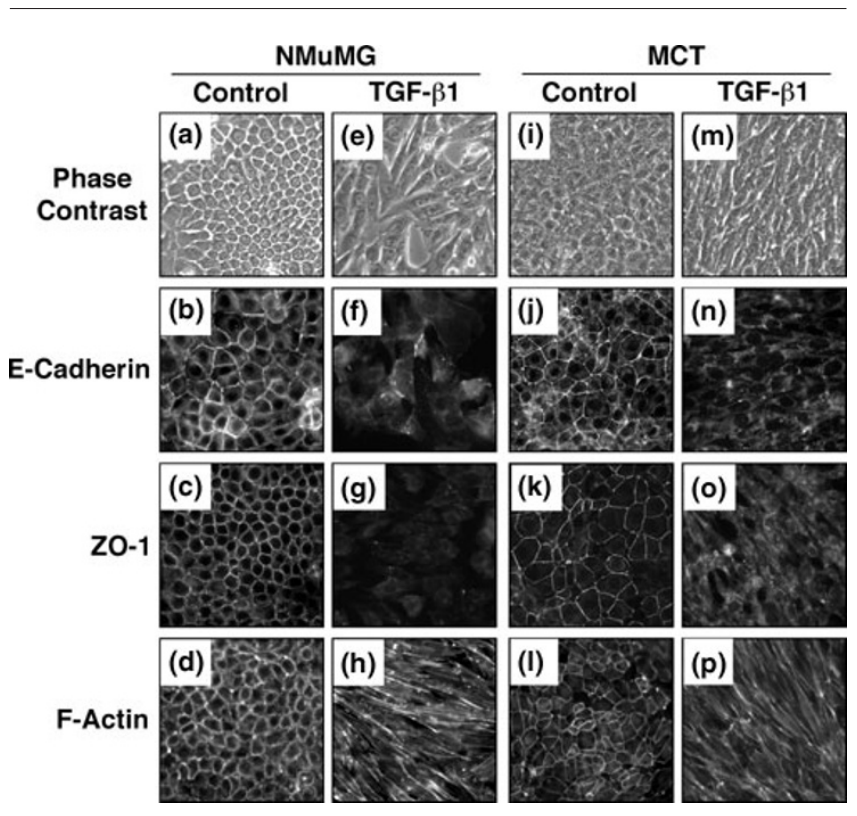

NMuMG and MCT cells underwent transforming growth factor (TGF)$\beta 1$-mediated epithelial to mesenchymal transition. Phase contrast images of $(\mathbf{a}, \mathbf{e})$ NMuMG and $(\mathrm{i}, \mathrm{m}) \mathrm{MCT}$ cells with (TGF- $\beta 1)$ and without (control) TGF- $\beta 1$ treatment $(5 \mathrm{ng} / \mathrm{ml})$ for 48 hours.

Immunofluorescence detection of $(\mathbf{b}, \mathbf{f}, \mathbf{j}, \mathbf{n})$ E-cadherin, $(\mathbf{c}, \mathbf{g}, \mathbf{k}, \mathbf{o})$ zonula occludens (ZO)-1, and (d,h,l,p) F-actin in NMuMG and MCT cells treated with $5 \mathrm{ng} / \mathrm{ml}$ TGF- $\beta 1$ (TGF- $\beta 1$ ) or without TGF- $\beta 1$ (control) for 48 hours. TGF- $\beta 1$ induced cell elongation, loss of cortical actin and junctional E-cadherin and ZO-1 staining, and formation of actin stress fibers in NMuMG and MCT cells. Micrographs are representative of at least three independent experiments.
Figure 2

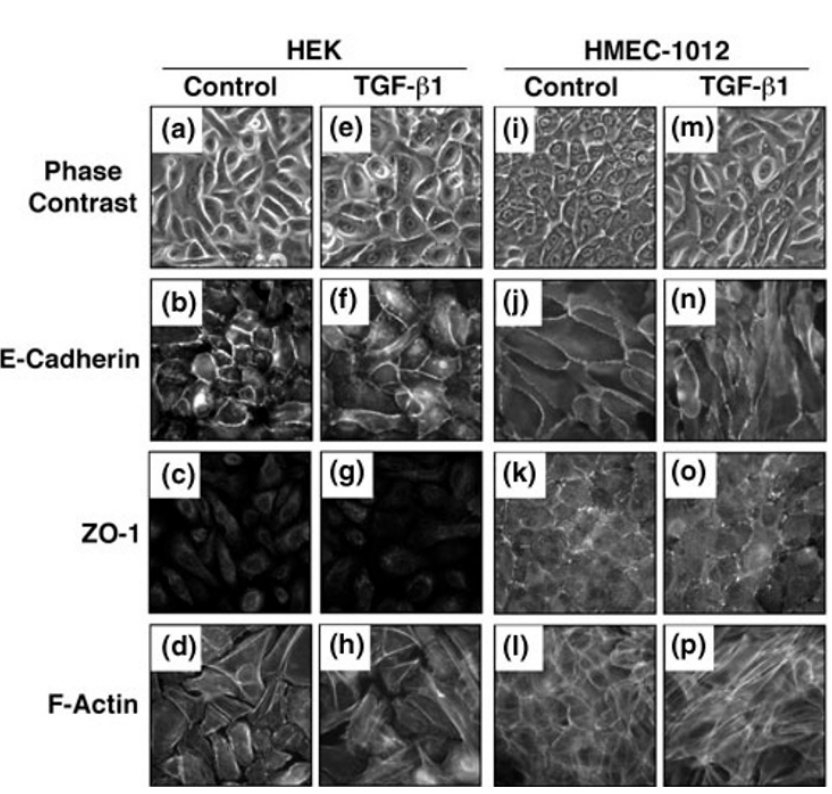

Transforming growth factor (TGF)- $\beta 1$ induced spindle-shaped morphology in nontransformed human mammary epithelial cells (HMECs) and human epidermal keratinocytes (HEKs). Phase contrast images of $(\mathrm{a}, \mathrm{e}) \mathrm{HEK}$ and $(\mathrm{i}, \mathrm{m}) \mathrm{HMEC}$ cells with (TGF- $\beta 1$ ) and without (control) TGF- $\beta 1$ treatment $(5 \mathrm{ng} / \mathrm{ml})$ for 48 hours. Immunofluorescence detection of $(\mathbf{b}, \mathbf{f}, \mathbf{j}, \mathbf{n}) \mathrm{E}$-cadherin, $(\mathbf{c}, \mathbf{g}, \mathbf{k}, \mathbf{o})$ zonula occludens (ZO)-1, and (d,h,l,p) F-actin in HEK and HMEC cells treated with $5 \mathrm{ng} / \mathrm{ml}$ TGF- $\beta 1$ (TGF- $\beta 1$ ) or without TGF- $\beta 1$ (control) for 48 hours. TGF- $\beta 1$ induced cell elongation and formation of actin stress fibers in the HEK and HMEC cells. However, junctional E-cadherin staining remained intact after TGF- $\beta 1$ treatment. ZO- 1 was not detected in the HEK cells and little was observed in the HMEC cells with or without TGF- $\beta 1$ treatment. Micrographs are representative of at least three independent experiments.

Table 2

\section{Summary of transforming growth factor- $\beta 1$-induced cellular responses in vitro}

\begin{tabular}{|c|c|c|c|c|}
\hline \multirow[b]{2}{*}{ Cell strain } & \multicolumn{4}{|c|}{ TGF- $\beta 1$-induced response ${ }^{a}$} \\
\hline & $\begin{array}{l}\text { Acquisition of } \\
\text { spindle shape }^{b}\end{array}$ & $\begin{array}{l}\text { Loss of junctional } \\
\text { E-cadherinc }\end{array}$ & Loss of junctional ZO-1c & $\begin{array}{l}\text { Actin stress fiber } \\
\text { formation }^{\circ}\end{array}$ \\
\hline HEK & \pm & - & $N / A^{d}$ & \pm \\
\hline HMECe & \pm & - & $N / A^{d}$ & + \\
\hline $\mathrm{HaCaT}$ & - & - & - & \pm \\
\hline Colo357 & - & - & - & \pm \\
\hline Panc-1 & - & - & - & - \\
\hline NMuMG & + & + & + & + \\
\hline MCT & + & + & + & + \\
\hline
\end{tabular}

aTreatment with $5 \mathrm{ng} / \mathrm{ml}$ transforming growth factor (TGF)- $\beta 1$ for 48 hours. ${ }^{b}$ Determined by phase contrast microscopy. ${ }^{\mathrm{C} D e t e r m i n e d ~ b y ~ E-c a d h e r i n, ~}$ zonula occludens (ZO)-1, or F-actin immunofluorescence. dHuman epidermal keratinocytes (HEKs) and human mammary epithelial cells (HMECs) exhibited little to no junctional ZO-1 staining in the absence of TGF- $\beta 1$ treatment. eHMECs from patients \#1012 and \#1016. Cellular responses to TGF- $\beta 1$ designated by + (strong), \pm (weak), or - (negative). 
Figure 3

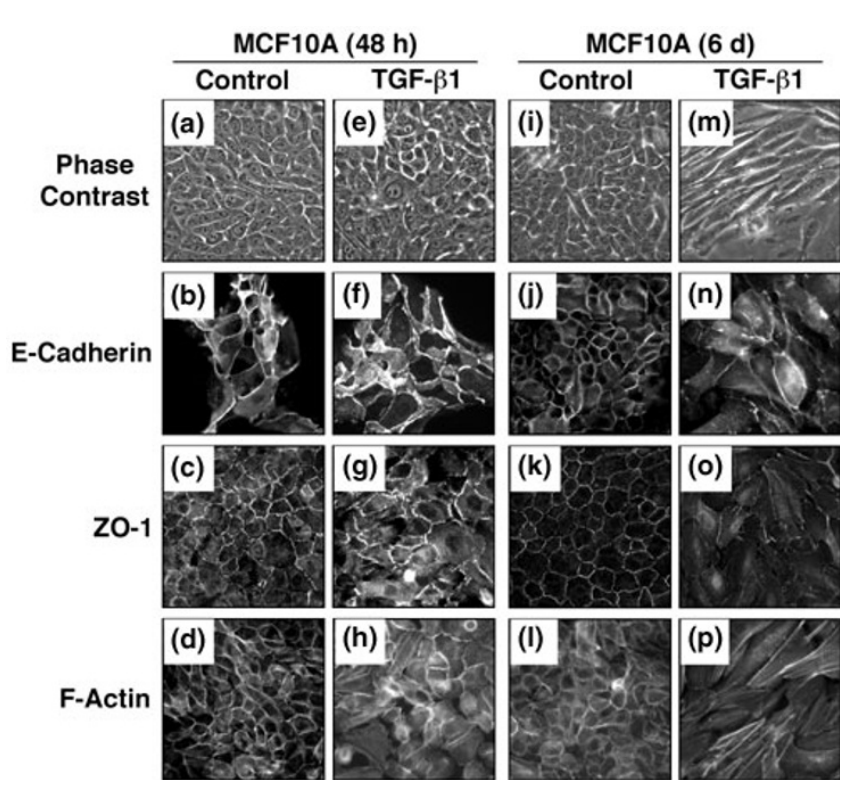

Elongation and loss of junctional E-cadherin and zonula occludens (ZO)-1 after prolonged transforming growth factor (TGF)- $\beta 1$ treatment in MCF10A cells. Phase contrast images of MCF10A cells treated with (TGF- $\beta 1$ ) or without (control) $5 \mathrm{ng} / \mathrm{ml}$ TGF- $\beta 1$ for $(\mathrm{a}, \mathrm{e}) 48$ hours or $(\mathrm{i}, \mathrm{m}) 6$ days. Immunofluorescence detection of $(\mathbf{b}, \mathrm{f}, \mathrm{j}, \mathrm{n}) \mathrm{E}$-cadherin, $(\mathbf{c}, \mathbf{g}, \mathbf{k}, \mathbf{0})$ ZO-1, and $(\mathbf{d}, \mathbf{h}, \mathbf{l}, \mathbf{p}) \mathrm{F}$-actin in MCF10A cells treated with TGF- $\beta 1$ ) or without (control) $5 \mathrm{ng} / \mathrm{ml}$ TGF- $\beta 1$ for 48 hours or 6 days. TGF- $\beta 1$ treatment induced cell elongation and formation of actin stress fibers in the MCF10A cells after 6 days of TGF- $\beta 1$ treatment but not after 48 hours. MCF10A cells also lost some junctional E-cadherin and ZO-1 after 6 days of treatment with TGF- $\beta 1$. Micrographs are representative of at least three independent experiments.

MDA-MB-231, A549, DU145, and EpH4 (Fig. 5 and Table 3). Only $22 \%$ of the cell strains screened showed greater than a $75 \%$ reduction in $\left[{ }^{3} \mathrm{H}\right]$ thymidine incorporation (or $25 \%$ of the control) after 48 hours of TGF- $\beta 1$ treatment (Fig. 5 and Table 3). These cells included HEK, HMEC (1012), MK, KC, NMuMG, and MCT (Fig. 5 and Table 3). Of note, established cell lines constituted $95 \%$ of the cells that did not have greater than $75 \%$ reduction in $\left[{ }^{3} \mathrm{H}\right]$ thymidine after TGF- $\beta 1$ treatment (Fig. 5 and Table 3).

Most of the cell lines that did not have a greater than 75\% reduction in $\left[{ }^{3} \mathrm{H}\right]$ thymidine incorporation after TGF- $\beta 1$ treatment, did not exhibit changes in morphology or changes in actin, E-cadherin, or ZO-1 localization in this screen (Figs 1-5; and data not shown). Only the UNC10, A549, and DU145 cell lines did not have reduced $\left[{ }^{3} \mathrm{H}\right]$ thymidine incorporation of greater than $75 \%$ and had increased actin stress fiber formation after TGF- $\beta 1$ treatment (Figs 4 and 5 ; and data not shown). However, there was no change in ZO-1 localization in these cells (data not shown). In comparison, all of the cell lines that had decreased $\left[{ }^{3} \mathrm{H}\right]$ thymidine incorporation had increased actin stress fiber formation after TGF- $\beta 1$ treatment (Fig. 1d,h,l,p; Fig. 2d,h,l,p; Fig. 3d,h,l,p; Fig. 4d,h,t,x; Fig. 5; and data not shown). These cells included the HaCaT, MCF10A, Colo357, MK, KC, NMuMG, 4T1, and MCT cells, and the primary cultures of HMEC-1012 and HEK cells.

Flow cytometry was also performed on cells treated with TGF- $\beta 1$ for 48 hours to confirm the data generated by $\left[{ }^{3} \mathrm{H}\right]$ thymidine incorporation. The data generated by flow cytometry experiments were consistent with those of $\left[{ }^{3} \mathrm{H}\right]$ thymidine incorporation (Figs 5 and 6, and Table 3). Fig. 6 includes histograms that were representative of cell strains with 0-25\% (MDA-MB-436), 25-75\% (EpH4), and $75-100 \%$ (NMuMG) reduction in S-phase after 48 hours of TGF- $\beta 1$ treatment, when compared with the control cells.

\section{Transforming growth factor- $\beta 1$-mediated Smad2} phosphorylation did not correlate with S-phase reduction To determine the relationship of Smad2 phosphorylation with reduction in S-phase and EMT, after TGF- $\beta 1$ treatment, we analyzed phosphorylated Smad2 protein levels. Western analyses of protein extracts showed that, after 2 hours of treatment with TGF- $\beta 1$, phosphorylated Smad2 protein levels increased in all of the cell strains screened except for the MCF7, MDA-MB-361, and MDA-MB-435S cells when normalized to actin (Fig. 7 and Table 3). After treatment with TGF- $\beta 1$ for 48 hours, levels of phosphorylated Smad2 remained elevated in the cells with increased levels of phosphorylated Smad2 after 2 hours of treatment, except HMEC (1016), HBL100, MCF10A, MDA-MB-436, H1299, MK, and MCT when normalized to actin (Figs 7 and 8, and Table 3). Immunoblot analysis of the MCF7, MDA-MB-361, and MDA-MB-435S cells with the phosphorylated Smad2 antibody (lot \#21034) resulted in a band (indicated by an asterisk) that migrated higher than the phosphorylated Smad2 protein (Fig. 7).

Cell strains that exhibited TGF- $\beta 1$-induced phosphorylation of Smad2 did not necessarily exhibit a reduction in $\left[{ }^{3} \mathrm{H}\right]$ thymidine uptake. These cell strains included SCC028, MDA-MB-436, MDA-MB-468, and H1299 (Figs 5 and 7, and Table 3). Although the MCF7 cells had $\left[{ }^{3} \mathrm{H}\right]$ thymidine uptake of $59 \%$ of the control after 48 hours of TGF- $\beta 1$ treatment, an increase in phosphorylation of Smad2 by Western analysis was not observed at 2 hours or at 48 hours (Figs 5, 7 and 8, and Table 3).

Prolonged transforming growth factor- $\beta 1$ treatment led to decreased total Smad2 and Smad3 protein levels in many cell strains

Total Smad2 and Smad3 protein levels decreased with TGF- $\beta 1$ treatment in $51 \%$ and $48 \%$ of the cell lines, respectively (Fig. 8). Total Smad2 levels decreased in HEK, HaCaT, SCC012, UNC10, BT549, MDA-MB-231, MDA-MB-361, MDA-MB-435S, H1299, Colo357, NMuMG, EpH4, 4T1, and MCT cells when normalized to 


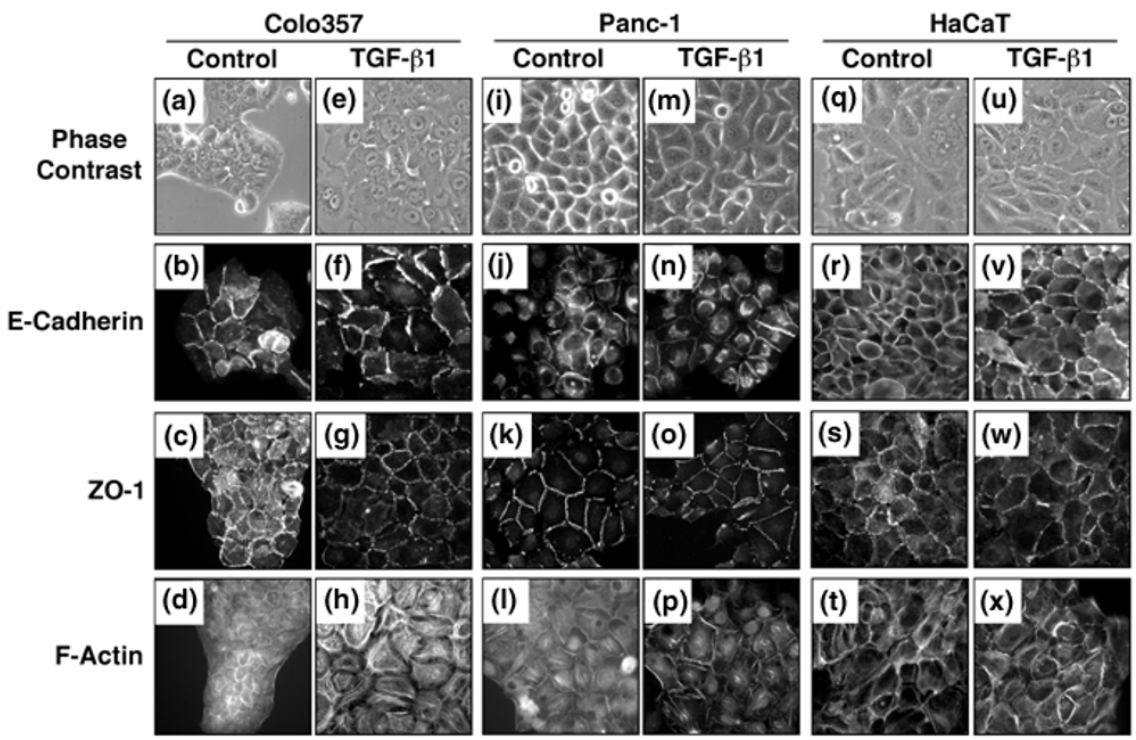

Transforming growth factor (TGF)- $\beta 1$ did not induce epithelial to mesenchymal transition in Colo357, Panc-1, or HaCaT Cells. Phase contrast images of (a,e) Colo357, (i,m) Panc-1, and (q,u) HaCaT cells treated with (TGF- $\beta 1$ ) or without (control) $5 \mathrm{ng} / \mathrm{ml}$ TGF- $\beta 1$ for 48 hours. Immunofluorescence detection of (b,f,j, , , r, v) E-cadherin, (c,g,k,o,s,w) zonula occludens (ZO)-1, and (d,h,l,p,t,x) F-actin in Colo357, Panc-1, and $\mathrm{HaCaT}$ cells treated with (TGF- $\beta 1$ ) or without (control) $5 \mathrm{ng} / \mathrm{ml}$ TGF- $\beta 1$ for 48 hours. TGF- $\beta 1$ treatment induced cell enlargement and formation of actin stress fibers in the Colo357 cells. However, junctional E-cadherin and ZO-1 remained intact after TGF- $\beta 1$ treatment. Changes in cell morphology, E-cadherin, ZO-1, or actin localization were not observed in the Panc-1 and HaCaT cells. Micrographs are representative of two experiments.

Figure 5

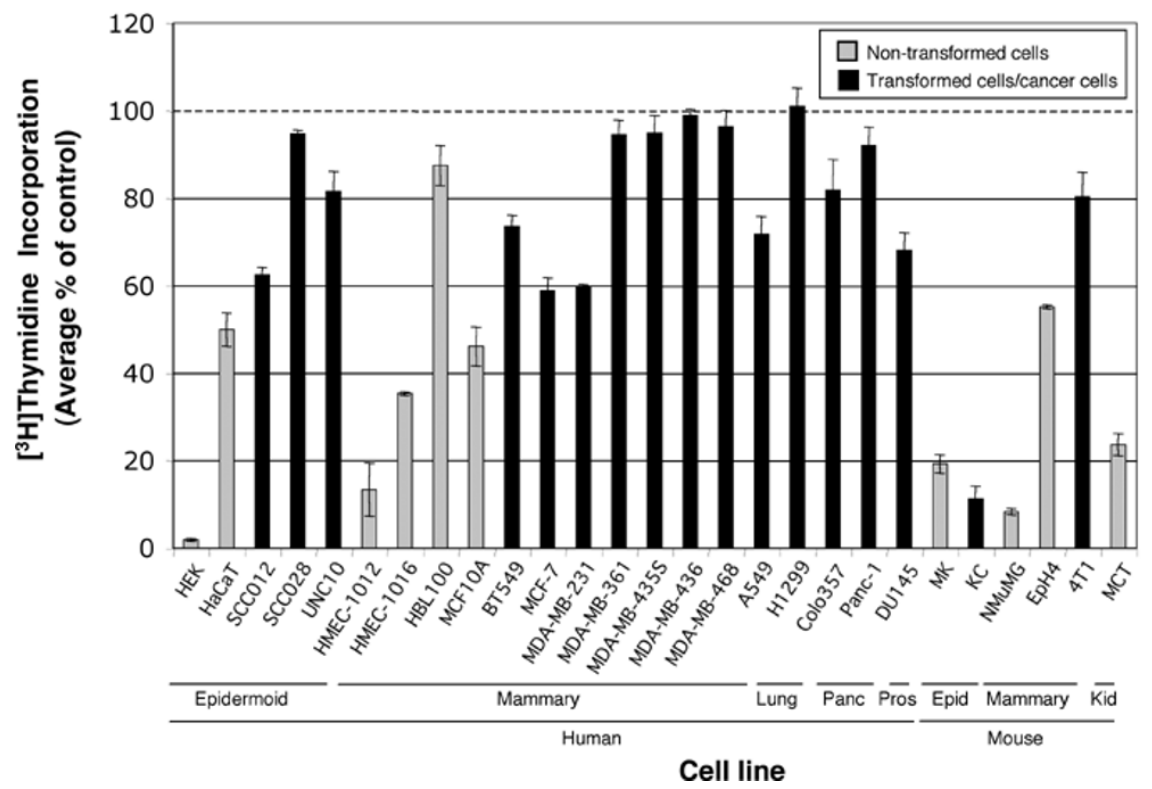

Many cancer cell lines were not growth inhibited by transforming growth factor (TGF)- $\beta 1$. Human primary cells and human and mouse established cell lines were treated with TGF- $\beta 1(5 \mathrm{ng} / \mathrm{ml})$ for 48 hours. The cells were then pulsed for 2 hours with $\left[{ }^{3} \mathrm{H}\right]$ thymidine, and incorporated radioactivity was quantified. Results are presented as the average percentage of control (untreated cells) incorporation ( \pm standard error) from three independent experiments with 6-12 replicates per experiment. The average percentage of control $\left[{ }^{3} \mathrm{H}\right]$ thymidine incorporation was calculated by dividing the average $\left[{ }^{3} \mathrm{H}\right]$ thymidine incorporation of TGF- $\beta 1$-treated cells (from three independent experiments) by the average $\left[{ }^{3} \mathrm{H}\right]$ thymidine incorporation of nontreated cells (from three independent experiments) and then multiplying by $100 \%$. Epid, epidermoid; Kid, kidney; Panc, pancreas; Pros, prostate. 
Table 3

Summary of transforming growth factor- $\beta 1$-mediated Smad signaling and effect on S-phase in vitro

\begin{tabular}{|c|c|c|c|c|c|}
\hline \multirow[b]{3}{*}{ Cell strain } & \multicolumn{5}{|c|}{ TGF- $\beta 1$-mediated response ${ }^{a}$} \\
\hline & \multirow{2}{*}{$\begin{array}{c}\text { Increase in } \\
\text { phosphorylated Smad2 }\end{array}$} & \multirow{2}{*}{$\begin{array}{l}\text { Decrease in total } \\
\text { Smad } 2^{c}\end{array}$} & \multirow{2}{*}{$\begin{array}{l}\text { Decrease in total } \\
\text { Smad3 } 3^{c}\end{array}$} & \multicolumn{2}{|c|}{ S-phase ( $\%$ of control \pm standard error) } \\
\hline & & & & {$\left[{ }^{3} \mathrm{H}\right] \mathrm{T}^{\mathrm{d}}$} & Flow $^{e}$ \\
\hline HEK & + & - & - & $2 \pm 0.3$ & $72 \pm 9$ \\
\hline $\mathrm{HaCaT}$ & + & + & + & $50 \pm 4$ & $86 \pm 11$ \\
\hline SCC012 & + & + & + & $63 \pm 2$ & $89 \pm 2$ \\
\hline SCCO28 & + & - & + & $95 \pm 1$ & $105 \pm 3$ \\
\hline UNC10 & + & + & + & $82 \pm 5$ & $96 \pm 1$ \\
\hline HMEC 1012 & + & - & + & $13 \pm 6$ & $47 \pm 6$ \\
\hline HMEC 1016 & $-^{*}$ & - & + & $35 \pm 0.4$ & $70 \pm 2$ \\
\hline HBL100 & $-^{*}$ & - & - & $87 \pm 5$ & $103 \pm 3$ \\
\hline MCF10A & $-^{*}$ & - & - & $46 \pm 5$ & $78 \pm 8$ \\
\hline BT549 & + & + & + & $74 \pm 3$ & $\mathrm{~N} / \mathrm{A}^{\mathrm{g}}$ \\
\hline MCF7 & - & - & - & $59 \pm 3$ & $81 \pm 4$ \\
\hline MDA-MB-231 & + & + & + & $60 \pm 1$ & $83 \pm 0.1$ \\
\hline MDA-MB-361 & - & + & - & $95 \pm 3$ & $98 \pm 2$ \\
\hline MDA-MB-435S & - & + & - & $95 \pm 4$ & $96 \pm 3$ \\
\hline MDA-MB-436 & $-^{*}$ & - & + & $99 \pm 1$ & $98 \pm 8$ \\
\hline MDA-MB-468 & + & - & - & $96 \pm 4$ & $98 \pm 1$ \\
\hline A549 & + & - & + & $72 \pm 4$ & $96 \pm 9$ \\
\hline H1299 & $-^{*}$ & + & - & $101 \pm 4$ & $107 \pm 3$ \\
\hline Colo357 & + & + & $-^{f}$ & $82 \pm 7$ & $69 \pm 5$ \\
\hline Panc-1 & + & - & - & $92 \pm 4$ & $95 \pm 6$ \\
\hline DU145 & + & - & - & $68 \pm 4$ & $83 \pm 8$ \\
\hline MK & $-{ }^{*}$ & - & - & $19 \pm 2$ & $38 \pm 7$ \\
\hline KC & + & - & - & $11 \pm 3$ & $27 \pm 4$ \\
\hline NMuMG & + & + & - & $8 \pm 1$ & $17 \pm 1$ \\
\hline $\mathrm{EpH} 4$ & + & + & + & $55 \pm 0.4$ & $84 \pm 4$ \\
\hline $4 \mathrm{~T} 1$ & + & + & + & $80 \pm 6$ & $91 \pm 1$ \\
\hline МCT & $-^{*}$ & + & - & $24 \pm 3$ & $87 \pm 8$ \\
\hline
\end{tabular}

aTreatment with $5 \mathrm{ng} / \mathrm{ml}$ transforming growth factor (TGF)- $\beta 1$ for 48 hours. bSimilar results obtained after 2 hours TGF- $\beta 1$ treatment except those designated by an asterisk (detected increased phosphorylated Smad2 after 2 hours of TGF- $\beta 1$ treatment). cNo decrease in total Smad2 or total Smad3 was detected after 2 hours of TGF- $\beta 1$ treatment. ${ }^{d}\left[{ }^{3} \mathrm{H}\right]$ Thymidine $\left(\left[{ }^{3} \mathrm{H}\right] \mathrm{T}\right)$ experiments performed at least three times with $6-12$ replicates. Results are presented as the average percent of control of three independent experiments. eFlow cytometry experiments performed at least three times in triplicate. Results are presented as the average percent of control of three independent experiments. ${ }^{\mathrm{f}} \mathrm{An}$ increase in total Smad3 was observed in Colo357 cells 48 hours after TGF- $\beta 1$ treatment. 9Accurate flow cytometry analysis could not be performed on BT549 cells because multiple populations of cells were present in the culture. Cellular responses to TGF- $\beta 1$ designated as + (positive response) or - (negative response). HEK, human epidermal keratinocyte; HMEC, human mammary epithelial cell; KC, mouse keratinocytes transformed with K-ras; MK, mouse keratinocyte.

actin (Fig. 8). Total Smad3 levels decreased in HEK, HMEC (1012 and 1016), HaCaT, SCC012, SCC028, UNC10, BT549, MDA-MB-231, MDA-MB-436, A549, EpH4, and $4 \mathrm{~T} 1$ cells when normalized to actin (Fig. 8).
Decreased total Smad2 and total Smad3 protein levels did not correlate with an increased reduction in S-phase after TGF- $\beta 1$ treatment for 48 hours. For instance, the HMEC (1012), MK, and KC cells had a $87 \%, 81 \%$, and 

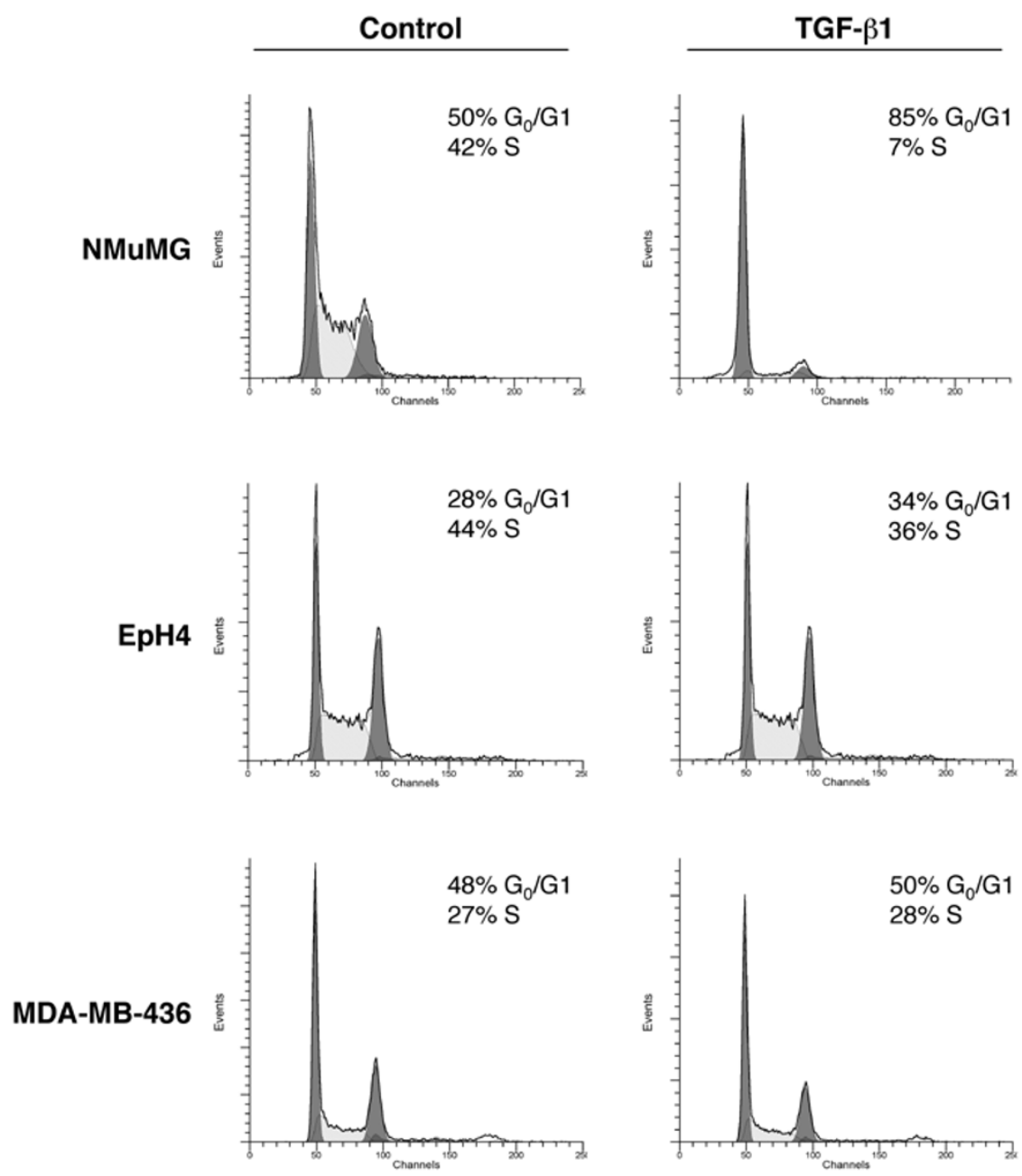

Transforming growth factor (TGF)- $\beta 1$ induced a robust decrease in S-phase in non-cancer cell strains. Human primary cells and human and mouse established cell lines were treated with (TGF- $\beta 1$ ) or without (control) $5 \mathrm{ng} / \mathrm{ml} \mathrm{TGF-} \beta 1$ for 48 hours. The cells were then harvested and incubated with propidium iodide, and DNA content was determined using a FACS Caliber (Becton-Dickinson). Data were modeled and analyzed using ModFit and WinList software (Verity Software House). Fifteen thousand events were analyzed for each sample. Representative histograms are presented illustrating cells that had a robust decrease in S-phase (NMuMG), modest decrease in S-phase (EpH4), and no decrease in S-phase (MDA-MB-436) as a result of TGF- $\beta 1$ treatment. $G_{0} / G 1$ and $G 2$ phases are indicated by black shading and $S$ phase is indicated by gray shading on the histograms. The percentage of cells in $G_{0} / G 1$ and in $S$ phases of the cell cycle are indicated. Three independent experiments were performed with three replicates per experiment.

$89 \%$ reduction in $\left[{ }^{3} \mathrm{H}\right]$ thymidine incorporation, respectively, whereas there was no decrease in total Smad2 protein levels after 48 hours of TGF- $\beta 1$ treatment (Figs 5 and 8 , and Table 3). Similarly, the MK, KC, MCT, and NMuMG cells had $81 \%, 89 \%, 76 \%$, and $92 \%$ reductions in $\left[{ }^{3} \mathrm{H}\right]$ thymidine incorporation, respectively, whereas there was no decrease in total Smad3 protein levels after 48 hours of TGF- $\beta 1$ treatment (Figs 5 and 8 , and Table 3 ). In contrast, the HEK cells had a $98 \%$ reduction in $\left[{ }^{3} \mathrm{H}\right]$ thymidine incorporation and had no reduction of total Smad2 or Smad3 after 48 hours of TGF- $\beta 1$ treatment (Figs 5 and 8, and Table 3).
Also, decreased total Smad2 and Smad3 protein levels did not correlate with an increase in the levels of phosphorylated Smad2 protein after TGF- $\beta 1$ treatment (Figs 7 and 8, and Table 3). An increase in phosphorylated Smad2 protein levels occurred in all cell strains screened after 2 hours of TGF- $\beta 1$ treatment except for the MCF7, MDAMB-361, and MDA-MB-435S cells (Fig. 7), whereas only a subset of those had decreased total Smad2 and/or Smad3 protein levels after TGF- $\beta 1$ treatment for 48 hours (Fig. 8 and Table 3). Additionally, the MDA-MB-361 and the MDA-MB-435S cells did not have increased phosphorylated Smad2 levels or decreased total Smad3 


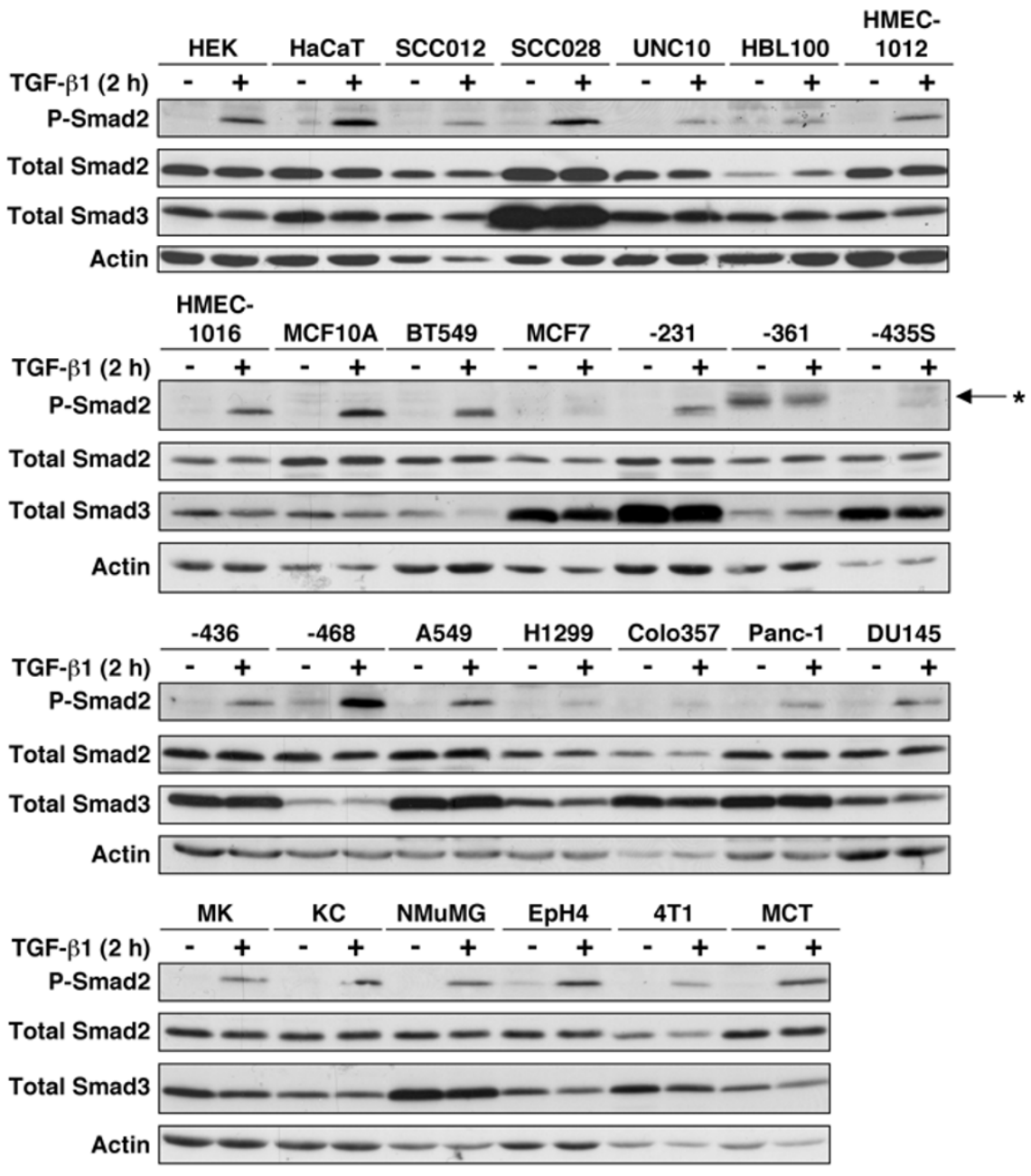

Transforming growth factor (TGF)- $\beta 1$ induced Smad2 phosphorylation in many cancer and noncancer cell strains. Twenty-four human and mouse established cell lines and three primary human cell cultures were treated with TGF- $\beta 1(5 \mathrm{ng} / \mathrm{ml})$ for 2 hours. Extracts from control (-) and treated $(+)$ cells were prepared and subjected to immunoblot analyses using antibodies for phosphorylated Smad2 (Ser 465/467), total Smad2, total Smad3, or actin. A signal of higher molecular weight, that is not phosphorylated Smad2, is indicated by an asterisk.

levels, but they did exhibit decreased total Smad2 levels after 48 hours of TGF- $\beta 1$ treatment (Figs 7 and 8, and Table 3).

The decrease in total Smad2 and Smad3 protein levels, observed after TGF- $\beta 1$ treatment, did not associate with the ability of the cell line to undergo TGF- $\beta 1$-mediated EMT. NMuMG and MCT cells underwent EMT (Fig. 1) and they both exhibited decreased total Smad2 and no decrease in total Smad3 protein levels after TGF- $\beta 1$ treatment for 48 hours (Fig. 8). The other cell lines that had decreased total Smad2 and no decrease in total Smad3 levels after TGF- $\beta 1$ treatment did not undergo TGF- $\beta 1$-induced EMT (Figs 2-4 and 8, and Table 3; and data not shown).

\section{Discussion}

TGF- $\beta 1$ is an inhibitor of epithelial cell growth in the early stages of carcinogenesis. However, it also promotes tumor cell invasion and metastasis through the induction of EMT [52]. Many studies on the mechanism of TGF- $\beta 1$ induced EMT are limited to a few murine cell lines and mouse models. Therefore, to identify alternative cell systems in which to study TGF- $\beta 1$-induced EMT, we performed a TGF- $\beta 1$ sensitivity screen using a panel of human primary cells and established human and mouse cell lines.

The TGF- $\beta 1$-induced morphologic changes observed in the NMuMG, MCT, and HMEC cells 48 hours after TGF$\beta 1$ treatment are consistent with changes seen during EMT (Fig. 1a,e,i,m; Fig. 2i,m; and data not shown) [53,54]. 


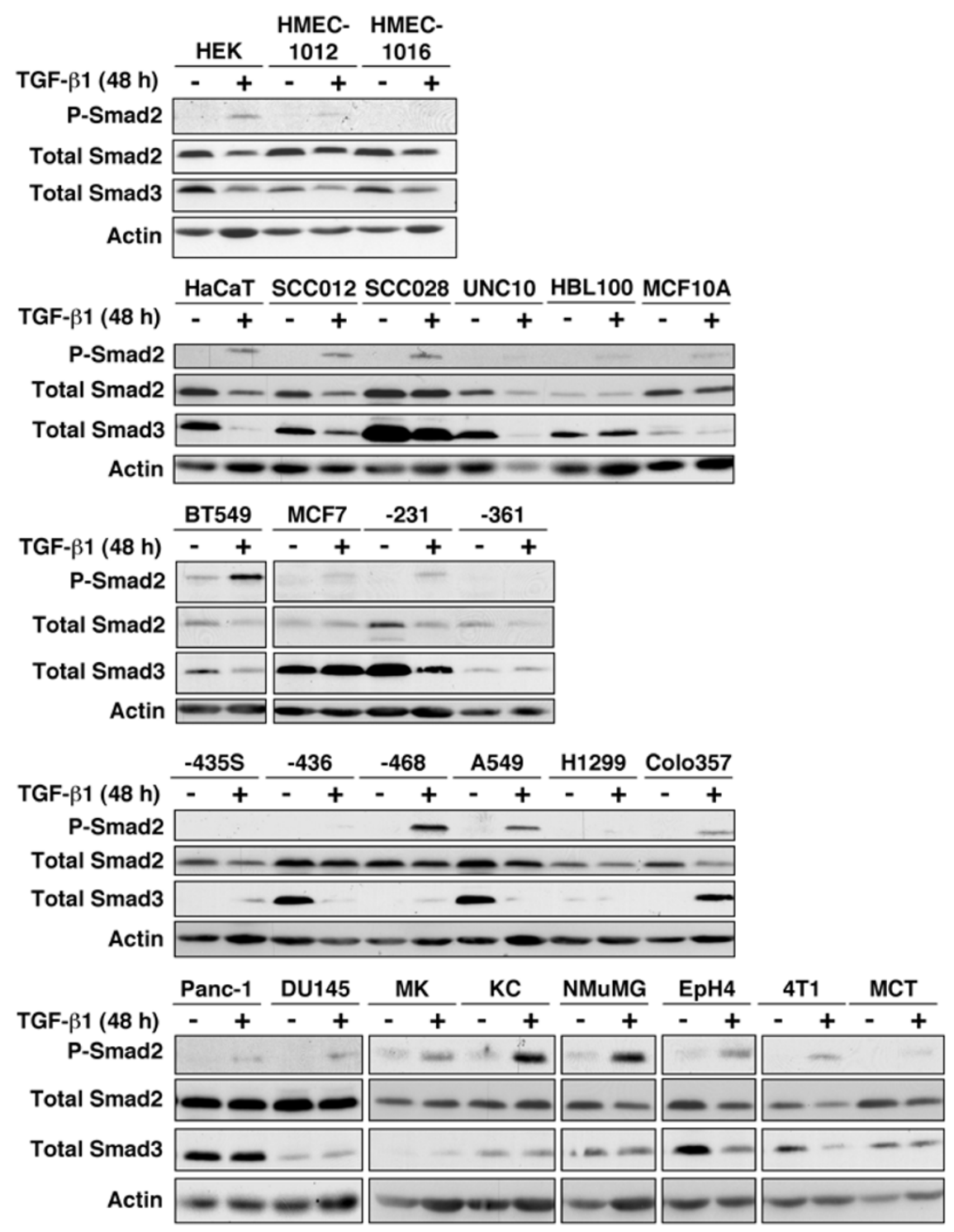

Prolonged transforming growth factor (TGF)- $\beta_{1}$ treatment induced a decrease in total Smad2 and/or Smad3 in many cell strains. Twenty-four human and mouse established cell lines and three primary human cell cultures were treated with TGF- $\beta 1$ ( $5 \mathrm{ng} / \mathrm{ml})$ for 48 hours. Extracts from control (-) and treated (+) cells were prepared and subjected to immunoblot analyses using antibodies for phosphorylated Smad2 (Ser 465/467), total Smad2, total Smad3, or actin.

Changes in cell morphology, from a cobblestone-like appearance to more elongated shape, and actin stress fiber formation, were observed in the NMuMG and MCT cells, and in primary cultures of HMECs (Fig. 1a,d,e,h,i,l,m,p; Fig. 2i,l,m,p; and data not shown). However, only the NMuMG and MCT cells lost E-cadherin and ZO-1 staining at the cell-cell junctions after 48 hours of TGF- $\beta 1$ treatment (Fig. 1b,f,j,n,c,g,k,o). E-cadherin is a protein found at adherens junctions that allows for cell-cell adherence, and ZO-1 is a tight junctional protein that forms a selective barrier between cells. Loss of these proteins at cell-cell actin is a measure of cell integrity and loss thereof, or formation of actin stress fibers, is also used to define EMT $[63,64]$. Therefore, we concluded that only the NMuMG and MCT cells underwent TGF- $\beta 1$-mediated EMT, after 48 hours of treatment, in this screen. Results from previous studies also show that NMuMG and MCT cells undergo TGF- $\beta 1$-mediated EMT [60,61,63-65]. Other studies reported that TGF- $\beta 1$-mediated EMT occurs in $\mathrm{HaCaT}$, Colo357, and Panc- 1 cells 48 hours after TGF- $\beta 1$ treatment $[66,67]$; however, they did not undergo TGF- $\beta 1$ induced EMT according to the conditions used in the present study (Fig. 4). Other cell lines screened in the 
study formed actin stress fibers with TGF- $\beta 1$ treatment, but they did not lose ZO-1 from cell-cell junctions (Fig. 3c,d,g,h; and data not shown). We did not examine E-cadherin localization in all of the cell strains because not all of the cell strains exhibited morphologic changes, with TGF- $\beta 1$ treatment, that were indicative of EMT.

Unlike the mouse NMuMG and MCT cells, none of the 14 human cell lines with an epithelial morphology screened underwent TGF- $\beta 1$-mediated EMT within 48 hours of TGF$\beta 1$ treatment. The MCF10A human breast epithelial cell line took 6 days to undergo a morphologic change, lose junctional E-cadherin and ZO-1, and form actin stress fibers with TGF- $\beta 1$ treatment (Fig. $3 i-p$ ). However, this extended treatment with TGF- $\beta 1$ to induce EMT is not consistent with previous reports that used times up to and including 48 hours $[60,61,66,67]$. It may be that the extended treatment with TGF- $\beta 1$ is necessary to activate secondary and tertiary signaling pathways that are not activated within 48 hours. The Panc-1, Colo357, and $\mathrm{HaCaT}$ cells were treated with TGF- $\beta 1$ for longer than 48 hours because they were shown to undergo TGF- $\beta 1$ induced EMT in previous reports $[66,67]$. However, these cell lines did not undergo EMT when treated with TGF- $\beta 1$ for 72 hours (data not shown). These data could suggest that human cells are more resistant to TGF- $\beta 1$-mediated EMT. Alternatively, the TGF- $\beta 1$ treatment times were not long enough to induce EMT, the small sample size used may not be representative, or the cells may not have the genetic alterations necessary for TGF- $\beta 1$ to induce EMT.

Activation of non-Smad signaling pathways is also implicated in TGF- $\beta 1$-mediated EMT. Many studies have shown a requirement for activated Ras/Raf/mitogen-activited protein kinase for TGF- $\beta 1$-mediated EMT in human, rat, or mouse epidermal, pancreas, intestine, liver, prostate, and mammary epithelial cells [67-76]. In the mouse mammary gland epithelial cell line EpH4, TGF- $\beta 1$ induces EMT and tumor formation in mice only when cells express oncogenic $\mathrm{H}$-Ras [73]. Furthermore, it has been shown that TGF- $\beta 1$ can activate Ras, and increased $\mathrm{H}$-Ras levels are required for nuclear accumulation of Smad2 [70]. Additionally, signaling through integrin $\beta 1$ [68] and activation of EGF receptor [62], RhoA [61], p38 mitogen-activited protein kinase [77], and phosphatidylinositol 3-kinase $[60,70,71]$ pathways are involved in or required for TGF- $\beta 1$-induced EMT.

The lack of TGF- $\beta 1$-mediated EMT in the human cells does not necessarily refute a role for TGF- $\beta 1$ in promoting EMT in vivo in human tumors. Human epithelial tumors can undergo mesenchymal conversions, providing a potential role for EMT in human metastasis. It has been shown that excess TGF- $\beta 1$ can promote EMT in human tumors in vivo. Increased levels of TGF- $\beta 1$ are observed in many human tumors [35-40,42,51,78-80], are often localized to the advancing edges of primary tumors and metastases, and are associated with poor clinical outcome $[39,41]$.

It is somewhat unexpected that TGF- $\beta 1$-induced EMT occurred in nontransformed cell lines, such as the NMUMG and MCT cells, because in vivo mouse studies show that TGF- $\beta 1$ promotes tumor cell invasion and metastasis in the later stages of carcinogenesis $[5,6]$. In one of these studies, targeted expression of TGF- $\beta 1$ to mouse suprabasal keratinocytes results in resistance to the formation of benign skin tumors, after long-term chemical carcinogenesis treatment. However, benign papillomas that develop become malignant at an accelerated rate and metastasis occur more rapidly than spontaneous tumors in control mice. Additionally, there are a high incidence of spindle cell carcinoma development in these mice, pointing to TGF- $\beta 1$-induction of EMT in vivo [38]. NMuMG and MCT cells may have the genetic alterations that allow for TGF- $\beta 1$-mediated EMT to occur.

Many studies on TGF- $\beta 1$-mediated EMT have emphasized that TGF- $\beta 1$ promotes carcinogenesis in stages. It is proposed that cells first lose sensitivity to the growth inhibitory effects of TGF- $\beta 1$, and subsequently TGF- $\beta 1$ can promote tumor progression and EMT [59]. MMH-D3 murine hepatocytes and $\mathrm{EpH} 4$ murine mammary gland epithelial cells undergo TGF- $\beta 1$-mediated EMT only when rendered insensitive to TGF- $\beta 1$-induced cell cycle arrest or apoptosis, by infection with active H-Ras $[59,70,73,81]$. However, the present study does not support this model because it shows that resistance to the growth inhibitory effects of TGF- $\beta 1$ is not a prerequisite for TGF- $\beta 1$-mediated EMT. The NMuMG and MCT cells exhibited a decrease in S-phase and underwent EMT after 48 hours of TGF- $\beta 1$ treatment (Figs 1, 5, and 6). Consistent with the present study were experiments performed by Nicolas and coworkers [72] that showed that increased Smad3 in MDCK cells restored growth inhibitory responses to TGF- $\beta 1$ but did not revert cells from a mesenchymal to an epithelial phenotype. Additionally, Chang and coworkers [49] observed that increased TGF$\beta 1$ expression in sarcoma cells increased cell tumorigenicity while inhibiting cell proliferation.

The trends observed with the analysis of the flow cytometry data were consistent with the $\left[{ }^{3} \mathrm{H}\right]$ thymidine incorporation data (Figs 5 and 6 and Table 3). However, the values for the percentage of the control cells in Sphase were not identical between $\left[{ }^{3} \mathrm{H}\right]$ thymidine incorporation and flow cytometry for each cell strain. This discrepancy can be accounted for by the fact that the data were generated using two different methodologies. $\left[{ }^{3} \mathrm{H}\right]$ thymidine incorporation examines DNA synthesis during the last 2 hours of the 48 -hour period, whereas flow cytometry examines DNA synthesis at the 48-hour time-point. Although the numeric data generated from the 
$\left[{ }^{3} \mathrm{H}\right]$ thymidine incorporation and flow cytometry experiments were not the same, the trends of TGF- $\beta 1$ induced decreases in DNA synthesis were consistent.

All but three of the cell strains screened had an increase in phosphorylated Smad2 protein levels after 2 hours of TGF- $\beta 1$ treatment, but not all of the cell lines that had increased phosphorylation of Smad2 had reduced S-phase after 48 hours of TGF- $\beta 1$ treatment. The SCC028, MDA-MB-436, MDA-MB-468, and H1299 cells had an increase in phosphorylated Smad2 levels after 2 hours of TGF- $\beta 1$ treatment, but they exhibited decreases in S-phase of only $5 \%, 1 \%, 4 \%$, and $4 \%$, respectively (Figs 5-7 and Table 3 ). The lack of S-phase decrease upon 48 hours of TGF- $\beta 1$ treatment may point to inactivation of or mutations in downstream proteins that could abolish TGF- $\beta 1$-mediated growth inhibition in these cells. The MCF7 cells did not exhibit an increase in phosphorylated Smad2 protein levels after 2 hours of TGF- $\beta 1$ treatment, but there was a $41 \%$ decrease in Sphase on 48 hours of TGF- $\beta 1$ treatment (Figs $5-7$ and Table 3). This decrease in S-phase is not as great a decrease as was exhibited by some of the other cell strains when treated with TGF- $\beta 1$ for 48 hours. The decrease could be explained by very low levels of phosphorylated Smad2 increase on TGF- $\beta 1$ treatment that was not detected by immunoblot analysis. Alternatively, it is possible that the TGF- $\beta 1$ signal was propagated by phosphorylation of Smad3.

Smad2 is not solely responsible for the propagation of TGF$\beta 1$ signals. Similar to Smad2, on TGF- $\beta 1$ binding to the $T \beta R$ II, Smad3 is phosphorylated by the TRRI, forms a complex with Smad4, translocates to nucleus, and regulates the activation of TGF- $\beta 1$ target genes. However, mutations or deletions in Smad3 are rare in human cancers. Reports by Graham and coworkers [82] and $\mathrm{Xu}$ and coworkers [83] suggest that loss of Smad3 may largely be responsible for the nonresponsiveness of some cells to TGF- $\beta 1$. The proliferation, migration, and invasion of normal extravillous trophoblast cells are under the control of TGF$\beta 1$. However, premalignant and malignant trophoblast cells, that have lost the Smad3 protein but retain functional Smad2, are resistant to the antiproliferative and anti-invasive effect of TGF- $\beta 1$. It is therefore possible that the attenuation of inhibition of S-phase or the induction of EMT by TGF- $\beta 1$ in the present study may be a result of mutation or loss of Smad3, even though the cells have increased phosphorylation of Smad2 on TGF- $\beta 1$ treatment.

Interestingly, decreased total Smad2 and Smad3 protein levels were observed after TGF- $\beta 1$ treatment regardless of changes in the levels of phosphorylated Smad2 protein or of whether cell proliferation was inhibited by TGF- $\beta 1$ (Figs 5-8). Similar to our findings, decreased total Smad2 cells after TGF- $\beta 1$ treatment [84]. In that report, the proteasome inhibitors MG-132 or lactacystin blocked Smad2 from TGF- $\beta 1$-induced degradation. In addition, Smad3 decreases have been reported during TGF- $\beta 1$ induced EMT in MDCK cells $[72,85]$ and after TGF- $\beta 1$ treatment of human lung epithelial cells [86]. In these studies, MDCK cells become refractory to the growth inhibitory effects of TGF- $\beta 1$ [72,85]. TGF- $\beta 1$ treatment of primary human fibroblasts and $\mathrm{HaCaT}$ cells also leads to decreased total Smad3 protein levels $[87,88]$.

A negative feedback loop could explain the decreases in total Smad2 and Smad3 protein levels after 48 hours of TGF- $\beta 1$ treatment. The E3 ubiquitin ligase Smurf has been shown to interact with Smads and promote their ubiquitination $[89,90]$. In this model, phosphorylated, nuclear Smad2 is ubiquitinated by Smurf2 and degraded by proteasomes $[89,90]$. Smad7 also interacts with Smurf2 and induces TGF- $\beta$ receptor degradation [91,92]. Phosphorylated Smad3 is also ubiquitinated by the ROC1SCFFbw1a E3 ligase complex, and subsequently degraded in the proteasome [88]. In order to prevent continuous Smad signaling in the absence of TGF- $\beta 1$ stimulation, Smad2 and Smad3 are negatively regulated by a number of proteins. Smad6 and Smad7 inhibit Smad2 and Smad3 activation by competing with Smad2 and Smad3 for binding to the TGF- $\beta$ receptors [93]. Smad6 and Smad7 are induced by activation of TGF- $\beta 1$ signaling and form a negative feedback loop [94-96]. However, the mechanism of decrease in total Smad2 and/or Smad3 in different cell strains on prolonged TGF- $\beta 1$ treatment remains unclear.

\section{Conclusion}

TGF- $\beta 1$ induction of EMT is a rare occurrence in vitro and is not limited to transformed cell lines. In fact, TGF- $\beta 1$ mediated EMT was only observed in nontumorigenic cells in the present study. Furthermore, there does not appear to be a correlation between loss of TGF- $\beta$-mediated growth inhibition and EMT. The inability of TGF- $\beta 1$ to induce EMT was not due to a total loss of TGF- $\beta 1$ signaling, as was evidenced by induction of Smad2 phosphorylation. In conclusion, our data indicate that the in vitro models used to study TGF- $\beta 1$ induction of EMT may not be as relevant to in vivo cancer progression as was previously assumed in the field.

\section{Competing interests}

None declared.

\section{Acknowledgements}

We thank the Vanderbilt University Toxicology Center tissue culture core facility (supported by NIH grant ES00267) and the Vanderbilt University Medical Center Cell Imaging Core Resource (supported by $\mathrm{NIH}$ grants CA68485 and DK20593). We would also like to thank Dr Brian Law, Dr Neil Bhowmick, Dr Matthew Westfall, Jamie Hearnes, and Kristy Schavolt for critical reading of the manuscript. The present study was also supported by NIH training grant T32CA09592 to KAB and R01 CA85492 and R01 CA102162 to HLM. 


\section{References}

1. Dennler S, Goumans MJ, ten Dijke P: Transforming growth factor beta signal transduction. J Leukoc Biol 2002, 71:731740.

2. Pepper MS: Transforming growth factor-beta: vasculogenesis, angiogenesis, and vessel wall integrity. Cytokine Growth Factor Rev 1997, 8:21-43.

3. Schuster N, Krieglstein K: Mechanisms of TGF-beta-mediated apoptosis. Cell Tissue Res 2002, 307:1-14.

4. Moustakas A, Pardali K, Gaal A, Heldin $\mathrm{CH}$ : Mechanisms of TGF-beta signaling in regulation of cell growth and differentiation. Immunol Lett 2002, 82:85-91.

5. Derynck R, Akhurst RJ, Balmain A: TGF-beta signaling in tumor suppression and cancer progression. Nat Genet 2001, 29:117129.

6. Akhurst RJ, Derynck R: TGF-beta signaling in cancer: a doubleedged sword. Trends Cell Biol 2001, 11:S44-S51.

7. Wakefield LM, Roberts AB: TGF-beta signaling: positive and negative effects on tumorigenesis. Curr Opin Genet Dev 2002, 12:22-29.

8. Kloos DU, Choi C, Wingender E: The TGF-beta-Smad network: introducing bioinformatic tools. Trends Genet 2002, 18:96103.

9. Massague J: How cells read TGF-beta signals. Nat Rev Mol Cell Biol 2000, 1:169-78

10. de Caestecker MP, Piek E, Roberts AB: Role of transforming growth factor-beta signaling in cancer. J Natl Cancer Inst 2000, 92:1388-1402.

11. Ten Dijke P, Goumans MJ, Itoh F, Itoh S: Regulation of cell proliferation by Smad proteins. J Cell Physio/ 2002, 191:1-16.

12. Heldin $\mathrm{CH}$, Miyazono $\mathrm{K}$, ten Dijke P: TGF-beta signalling from cell membrane to nucleus through SMAD proteins. Nature 1997, 390:465-471.

13. Massague J, Wotton D: Transcriptional control by the TGFbeta/Smad signaling system. Embo J 2000, 19:1745-1754.

14. Gorska AE, Jensen RA, Shyr Y, Aakre ME, Bhowmick NA, Moses HL: Transgenic mice expressing a dominant-negative mutant type II transforming growth factor-beta receptor exhibit impaired mammary development and enhanced mammary tumor formation. Am J Pathol 2003, 163:1539-1549.

15. Amendt C, Schirmacher $\mathrm{P}$, Weber $\mathrm{H}$, Blessing M: Expression of a dominant negative type II TGF-beta receptor in mouse skin results in an increase in carcinoma incidence and an acceleration of carcinoma development. Oncogene 1998, 17:25-34.

16. Garrigue-Antar L, Munoz-Antonia T, Antonia SJ, Gesmonde J, Vellucci VF, Reiss M: Missense mutations of the transforming growth factor beta type II receptor in human head and neck squamous carcinoma cells. Cancer Res 1995, 55:3982-3987.

17. Chen T, Yan W, Wells RG, Rimm DL, McNiff J, Leffell D, Reiss M: Novel inactivating mutations of transforming growth factorbeta type I receptor gene in head-and-neck cancer metastases. Int J Cancer 2001, 93:653-661.

18. Munoz-Antonia T, Li X, Reiss M, Jackson R, Antonia S: A mutation in the transforming growth factor beta type II receptor gene promoter associated with loss of gene expression. Cancer Res 1996, 56:4831-4835.

19. Hougaard S, Norgaard P, Abrahamsen N, Moses HL, SpangThomsen M, Skovgaard Poulsen $\mathrm{H}$ : Inactivation of the transforming growth factor beta type II receptor in human small cell lung cancer cell lines. Br J Cancer 1999, 79:1005-1011.

20. Park K, Kim SJ, Bang YJ, Park JG, Kim NK, Roberts AB, Sporn $M B:$ Genetic changes in the transforming growth factor beta (TGF-beta) type II receptor gene in human gastric cancer cells: correlation with sensitivity to growth inhibition by TGFbeta. Proc Natl Acad Sci USA 1994, 91:8772-8776.

21. Kang SH, Bang YJ, Im YH, Yang HK, Lee DA, Lee HY, Lee HS, Kim NK, Kim SJ: Transcriptional repression of the transforming growth factor-beta type I receptor gene by DNA methylation results in the development of TGF-beta resistance in human gastric cancer. Oncogene 1999, 18:7280-7286.

22. Myeroff LL, Parsons R, Kim SJ, Hedrick L, Cho KR, Orth K, Mathis $M$, Kinzler KW, Lutterbaugh J, Park K: A transforming growth factor beta receptor type II gene mutation common in colon and gastric but rare in endometrial cancers with microsatellite instability. Cancer Res 1995, 55:5545-5547.

23. Markowitz S, Wang J, Myeroff L, Parsons R, Sun L, Lutterbaugh J, Fan RS, Zborowska E, Kinzler KW, Vogelstein B, Brattain M,
Wilson JKV: Inactivation of the type II TGF-beta receptor in colon cancer cells with microsatellite instability. Science 1995, 268:1336-1338.

24. Grady WM, Myeroff LL, Swinler SE, Rajput A, Thiagalingam S, Lutterbaugh JD, Neumann A, Brattain MG, Chang J, Kim SJ, Kinzler KW, Vogelstein B, Willson JK, Markowitz S: Mutational inactivation of transforming growth factor beta receptor type II in microsatellite stable colon cancers. Cancer Res 1999, 59:320-324.

25. Markowitz S: TGF-beta receptors and DNA repair genes, coupled targets in a pathway of human colon carcinogenesis. Biochim Biophys Acta 2000, 1470:M13-M20.

26. Goggins M, Shekher M, Turnacioglu K, Yeo CJ, Hruban RH, Kern SE: Genetic alterations of the transforming growth factor beta receptor genes in pancreatic and biliary adenocarcinomas. Cancer Res 1998, 58:5329-5332.

27. Wang D, Kanuma T, Mizunuma H, Takama F, lbuki Y, Wake N, Mogi A, Shitara Y, Takenoshita S: Analysis of specific gene mutations in the transforming growth factor-beta signal transduction pathway in human ovarian cancer. Cancer Res 2000 60:4507-4512.

28. Chen T, Triplett J, Dehner B, Hurst B, Colligan B, Pemberton J, Graff JR, Carter JH: Transforming growth factor-beta receptor type I gene is frequently mutated in ovarian carcinomas. Cancer Res 2001, 61:4679-4682.

29. Lucke CD, Philpott A, Metcalfe JC, Thompson AM, HughesDavies L, Kemp PR, Hesketh R: Inhibiting mutations in the transforming growth factor beta type 2 receptor in recurrent human breast cancer. Cancer Res 2001, 61:482-485.

30. Chen T, Carter D, Garrigue-Antar L, Reiss M: Transforming growth factor beta type I receptor kinase mutant associated with metastatic breast cancer. Cancer Res 1998, 58:48054810

31. Yanagisawa K, Uchida $K$, Nagatake $M$, Masuda A, Sugiyama M, Saito T, Yamaki K, Takahashi T, Osada H: Heterogeneities in the biological and biochemical functions of Smad2 and Smad4 mutants naturally occurring in human lung cancers. Oncogene 2000, 19:2305-2311.

32. Hahn SA, Schutte M, Hoque AT, Moskaluk CA, da Costa LT, Rozenblum E, Weinstein CL, Fischer A, Yeo CJ, Hruban RH, Kern SE: DPC4, a candidate tumor suppressor gene at human chromosome 18q21.1. Science 1996, 271:350-353.

33. Salovaara $R$, Roth $S$, Loukola A, Launonen V, Sistonen $P$, Avizienyte $E$, Kristo $P$, Jarvinen $H$, Souchelnytskyi $S$, SarlomoRikala M, Aaltonen LA: Frequent loss of SMAD4/DPC4 protein in colorectal cancers. Mol Pathol 2002, 55:385-388.

34. Eppert K, Scherer SW, Ozcelik H, Pirone R, Hoodless $P$, Kim H, Tsui LC, Bapat B, Gallinger S, Andrulis IL, Thomsen GH, Wrana $\mathrm{J}$, Attisano L: MADR2 maps to 18q21 and encodes a TGFbetaregulated MAD-related protein that is functionally mutated in colorectal carcinoma. Cell 1996, 86:543-552.

35. Krieg P, Schnapke R, Furstenberger G, Vogt I, Marks F: TGF-beta 1 and skin carcinogenesis: antiproliferative effect in vitro and TGF-beta 1 mRNA expression during epidermal hyperproliferation and multistage tumorigenesis. Mol Carcinog 1991, 4: 129-137.

36. Maehara Y, Kakeji Y, Kabashima A, Emi Y, Watanabe A, Akazawa $\mathrm{K}$, Baba $\mathrm{H}$, Kohnoe $\mathrm{S}$, Sugimachi $\mathrm{K}$ : Role of transforming growth factor-beta 1 in invasion and metastasis in gastric carcinoma. J Clin Oncol 1999, 17:607-614.

37. Gomella LG, Sargent ER, Wade TP, Anglard P, Linehan WM, Kasid A: Expression of transforming growth factor alpha in normal human adult kidney and enhanced expression of transforming growth factors alpha and beta 1 in renal cell carcinoma. Cancer Res 1989, 49:6972-6975.

38. Travers MT, Barrett-Lee PJ, Berger U, Luqmani YA, Gazet JC, Powles TJ, Coombes RC: Growth factor expression in normal benign, and malignant breast tissue. $\mathrm{Br}$ Med J (Clin Res Ed) 1988, 296:1621-1624.

39. Gorsch SM, Memoli VA, Stukel TA, Gold LI, Arrick BA: Immunohistochemical staining for transforming growth factor beta 1 associates with disease progression in human breast cancer. Cancer Res 1992, 52:6949-6952.

40. Walker RA, Dearing SJ: Transforming growth factor beta 1 in ductal carcinoma in situ and invasive carcinomas of the breast. Eur J Cancer 1992, 28:641-644.

41. Dalal $\mathrm{BI}$, Keown PA, Greenberg AH: Immunocytochemical localization of secreted transforming growth factor-beta 1 to the 
advancing edges of primary tumors and to lymph node metastases of human mammary carcinoma. Am J Pathol 1993, 143:381-389.

42. Steiner MS, Zhou ZZ, Tonb DC, Barrack ER: Expression of transforming growth factor-beta 1 in prostate cancer. Endocrinology 1994, 135:2240-2247.

43. Muraoka RS, Dumont N, Ritter CA, Dugger TC, Brantley DM, Chen J, Easterly E, Roebuck LR, Ryan S, Gotwals PJ, Koteliansky $\mathrm{V}$, Arteaga CL: Blockade of TGF-beta inhibits mammary tumor cell viability, migration, and metastases. J Clin Invest 2002, 109:1551-1559.

44. Caulin C, Scholl FG, Frontelo P, Gamallo C, Quintanilla M: Chronic exposure of cultured transformed mouse epidermal cells to transforming growth factor-beta 1 induces an epithelial-mesenchymal transdifferentiation and a spindle tumoral phenotype. Cell Growth Differ 1995, 6:1027-1035.

45. Portella G, Cumming SA, Liddell J, Cui W, Ireland H, Akhurst RJ, Balmain A: Transforming growth factor beta is essential for spindle cell conversion of mouse skin carcinoma in vivo: implications for tumor invasion. Cell Growth Differ 1998, 9: 393-404.

46. Arrick BA, Lopez AR, Elfman F, Ebner R, Damsky CH, Derynck R: Altered metabolic and adhesive properties and increased tumorigenesis associated with increased expression of transforming growth factor beta 1. J Cell Biol 1992, 118:715-726.

47. Tobin SW, Douville K, Benbow U, Brinckerhoff CE, Memoli VA, Arrick BA: Consequences of altered TGF-beta expression and responsiveness in breast cancer: evidence for autocrine and paracrine effects. Oncogene 2002, 21:108-118.

48. Steiner MS, Barrack ER: Transforming growth factor-beta 1 overproduction in prostate cancer: effects on growth in vivo and in vitro. Mol Endocrinol 1992, 6:15-25.

49. Chang HL, Gillett N, Figari I, Lopez AR, Palladino MA, Derynck R: Increased transforming growth factor beta expression inhibits cell proliferation in vitro, yet increases tumorigenicity and tumor growth of Meth A sarcoma cells. Cancer Res 1993, 53: 4391-4398.

50. Walker RA, Dearing SJ, Gallacher B: Relationship of transforming growth factor beta 1 to extracellular matrix and stromal infiltrates in invasive breast carcinoma. $\mathrm{Br} J$ Cancer 1994, 69: 1160-1165.

51. Welch DR, Fabra A, Nakajima M: Transforming growth factor beta stimulates mammary adenocarcinoma cell invasion and metastatic potential. Proc Natl Acad Sci USA 1990, 87:76787682.

52. Akhurst RJ, Balmain A: Genetic events and the role of TGF beta in epithelial tumour progression. J Pathol 1999, 187:82-90.

53. Thiery JP: Epithelial-mesenchymal transitions in tumour progression. Nat Rev Cancer 2002, 2:442-454

54. Savagner P: Leaving the neighborhood: molecular mechanisms involved during epithelial-mesenchymal transition. Bioessays 2001, 23:912-923.

55. Birchmeier W, Birchmeier C: Epithelial-mesenchymal transitions in development and tumor progression. EXS 1995, 74:115.

56. Birchmeier C, Meyer D, Riethmacher D: Factors controlling growth, motility, and morphogenesis of normal and malignant epithelial cells. Int Rev Cytol 1995, 160:221-266.

57. Hay ED: Role of cell-matrix contacts in cell migration and epithelial-mesenchymal transformation. Cell Differ Dev 1990, 32:367-375

58. Sipes NJ, Lyons RM, Moses HL: Isolation and characterization of Kirsten murine sarcoma virus-transformed mouse keratinocytes resistant to transforming growth factor beta. $\mathrm{Mol}$ Carcinog 1990, 3:12-19.

59. Lehmann $K$, Janda $E$, Pierreux $C E$, Rytomaa M, Schulze $A$, McMahon M, Hill CS, Beug $H$, Downward J: Raf induces TGFbeta production while blocking its apoptotic but not invasive responses: a mechanism leading to increased malignancy in epithelial cells. Genes Dev 2000, 14:2610-2622.

60. Bakin AV, Tomlinson AK, Bhowmick NA, Moses HL, Arteaga CL: Phosphatidylinositol 3-kinase function is required for transforming growth factor beta-mediated epithelial to mesenchymal transition and cell migration. J Biol Chem 2000, 275: 36803-36810.

61. Bhowmick NA, Ghiassi M, Bakin A, Aakre M, Lundquist CA, Engel ME, Arteaga CL, Moses HL: Transforming growth factor-beta1 mediates epithelial to mesenchymal transdifferentiation through a RhoA-dependent mechanism. Mol Biol Cell 2001, 12:27-36.

62. Grande M, Franzen A, Karlsson JO, Ericson LE, Heldin NE, Nilsson M: Transforming growth factor-beta and epidermal growth factor synergistically stimulate epithelial to mesenchymal transition (EMT) through a MEK-dependent mechanism in primary cultured pig thyrocytes. J Cell Sci 2002, 115:42274236.

63. Miettinen PJ, Ebner R, Lopez AR, Derynck R: TGF-beta induced transdifferentiation of mammary epithelial cells to mesenchymal cells: involvement of type I receptors. J Cell Biol 1994, 127:2021-2036

64. Piek E, Moustakas A, Kurisaki A, Heldin $\mathrm{CH}$, ten Dijke P: TGF(beta) type I receptor/ALK-5 and Smad proteins mediate epithelial to mesenchymal transdifferentiation in NMuMG breast epithelial cells. J Cell Sci 1999, 112(Pt 24):4557-4568.

65. Okada H, Danoff TM, Kalluri R, Neilson EG: Early role of Fsp1 in epithelial-mesenchymal transformation. Am J Physiol 1997 273:F563-F574.

66. Zavadil J, Bitzer M, Liang D, Yang YC, Massimi A, Kneitz S, Piek E, Bottinger EP: Genetic programs of epithelial cell plasticity directed by transforming growth factor-beta. Proc Natl Acad Sci USA 2001, 98:6686-6691.

67. Ellenrieder V, Hendler SF, Boeck W, Seufferlein T, Menke A, Ruhland C, Adler G, Gress TM: Transforming growth factor beta1 treatment leads to an epithelial-mesenchymal transdifferentiation of pancreatic cancer cells requiring extracellular signal-regulated kinase 2 activation. Cancer Res 2001, 61: $4222-4228$.

68. Bhowmick N, Zent R, Ghaissi M, McDonnell M, Moses HL: Integrin b1 signaling is necessary for transforming growth factorbeta activation of p38MAPK and epithelial plasticity. J Biol Chem 2001, 276:46707-46713.

69. Fujimoto K, Sheng H, Shao J, Beauchamp RD: Transforming growth factor-beta1 promotes invasiveness after cellular transformation with activated Ras in intestinal epithelial cells. Exp Cell Res 2001, 266:239-249.

70. Gotzmann J, Huber $H$, Thallinger $C$, Wolschek M, Jansen $B$ Schulte-Hermann R, Beug H, Mikulits W: Hepatocytes convert to a fibroblastoid phenotype through the cooperation of TGFbeta1 and Ha-Ras: steps towards invasiveness. J Cell $\mathrm{Sci}$ 2002, 115:1189-1202.

71. Janda E, Lehmann K, Killisch I, Jechlinger M, Herzig M, Downward J, Beug H, Grunert S: Ras and TGF[beta] cooperatively regulate epithelial cell plasticity and metastasis: dissection of Ras signaling pathways. J Cell Bio/ 2002, 156:299-313.

72. Nicolas FJ, Lehmann K, Warne PH, Hill CS, Downward J: Epithelial mesenchymal transition in MDCK cells is accompanied by downregulation of Smad3 expression leading to resistance to TGFbeta-induced growth arrest. J Biol Chem 2002, 278:32513256.

73. Oft M, Peli J, Rudaz C, Schwarz H, Beug H, Reichmann E: TGFbeta1 and Ha-Ras collaborate in modulating the phenotypic plasticity and invasiveness of epithelial tumor cells. Genes Dev 1996, 10:2462-2477.

74. Oft $\mathrm{M}$, Heider $\mathrm{KH}$, Beug $\mathrm{H}$ : TGFbeta signaling is necessary for carcinoma cell invasiveness and metastasis. Curr Biol 1998, 8:1243-1252.

75. Oft M, Akhurst RJ, Balmain A: Metastasis is driven by sequential elevation of $\mathrm{H}$-ras and Smad2 levels. Nat Cell Biol 2002, 4: 487-494.

76. Park BJ, Park Jl, Byun DS, Park JH, Chi SG: Mitogenic conversion of transforming growth factor-beta1 effect by oncogenic Ha-Ras-induced activation of the mitogen-activated protein kinase signaling pathway in human prostate cancer. Cancer Res 2000, 60:3031-3038.

77. Bakin AV, Rinehart C, Tomlinson AK, Arteaga CL: p38 mitogenactivated protein kinase is required for TGFbeta-mediated fibroblastic transdifferentiation and cell migration. J Cell Sci 2002, 115:3193-3206.

78. Donnelly MJ, Patel V, Yeudall WA, Game SM, Scully C, Prime SS: Autocrine production of TGF-alpha and TGF-beta during tumour progression of rat oral keratinocytes. Carcinogenesis $1993,14: 981-985$.

79. Glynne-Jones E, Harper ME, Goddard L, Eaton CL, Matthews PN, Griffiths $\mathrm{K}$ : Transforming growth factor beta 1 expression in 
benign and malignant prostatic tumors. Prostate 1994, 25: 210-218.

80. Derynck R, Goeddel DV, Ullrich A, Gutterman JU, Williams RD, Bringman TS, Berger WH: Synthesis of messenger RNAs for transforming growth factors alpha and beta and the epidermal growth factor receptor by human tumors. Cancer Res 1987, 47:707-712.

81. Filmus J, Zhao J, Buick RN: Overexpression of H-ras oncogene induces resistance to the growth-inhibitory action of transforming growth factor beta-1 (TGF-beta 1) and alters the number and type of TGF-beta 1 receptors in rat intestinal epithelial cell clones. Oncogene 1992, 7:521-526.

82. Graham $\mathrm{CH}$, Connelly I, MacDougall JR, Kerbel RS, StetlerStevenson WG, Lala PK: Resistance of malignant trophoblast cells to both the anti-proliferative and anti-invasive effects of transforming growth factor-beta. Exp Cell Res 1994, 214:9399.

83. Xu G, Chakraborty C, Lala PK: Expression of TGF-beta signaling genes in the normal, premalignant, and malignant human trophoblast: loss of smad3 in choriocarcinoma cells. Biochem Biophys Res Commun 2001, 287:47-55.

84. Lo RS, Massague J: Ubiquitin-dependent degradation of TGFbeta-activated smad2. Nat Cell Biol 1999, 1:472-478.

85. Nicolas FJ, Lehmann K, Warne PH, Hill CS, Downward J: Epithelial to mesenchymal transition in Madin-Darby canine kidney cells is accompanied by down-regulation of Smad3 expression, leading to resistance to transforming growth factorbeta-induced growth arrest. J Biol Chem 2003, 278: 3251-3256.

86. Yanagisawa $\mathrm{K}$, Osada $\mathrm{H}$, Masuda $\mathrm{A}$, Kondo M, Saito T, Yatabe $\mathrm{Y}$, Takagi K, Takahashi T: Induction of apoptosis by Smad3 and down-regulation of Smad3 expression in response to TGFbeta in human normal lung epithelial cells. Oncogene 1998, 17:1743-1747.

87. Mori N, Morishita M, Tsukazaki T, Giam CZ, Kumatori A, Tanaka Y, Yamamoto N: Human T-cell leukemia virus type I oncoprotein Tax represses Smad-dependent transforming growth factor beta signaling through interaction with CREB-binding protein/p300. Blood 2001, 97:2137-2144.

88. Fukuchi M, Imamura T, Chiba T, Ebisawa T, Kawabata M, Tanaka $\mathrm{K}$, Miyazono K: Ligand-dependent degradation of Smad3 by a ubiquitin ligase complex of ROC1 and associated proteins. Mol Biol Cell 2001, 12:1431-1443.

89. Lin $\mathrm{X}$, Liang $\mathrm{M}$, Feng $\mathrm{XH}$ : Smurf2 is a ubiquitin E3 ligase mediating proteasome-dependent degradation of Smad2 in transforming growth factor-beta signaling. J Biol Chem 2000, 275: 36818-36822.

90. Zhang Y, Chang C, Gehling DJ, Hemmati-Brivanlou A, Derynck R: Regulation of Smad degradation and activity by Smurf2, an E3 ubiquitin ligase. Proc Natl Acad Sci USA 2001, 98:974-979.

91. Kavsak P, Rasmussen RK, Causing CG, Bonni S, Zhu H, Thomsen GH, Wrana JL: Smad7 binds to Smurf2 to form an E3 ubiquitin ligase that targets the TGF beta receptor for degradation. Mol Cell 2000, 6:1365-1375.

92. Ebisawa T, Fukuchi M, Murakami G, Chiba T, Tanaka K, Imamura $\mathrm{T}$, Miyazono K: Smurf1 interacts with transforming growth factor-beta type I receptor through Smad7 and induces receptor degradation. J Biol Chem 2001, 276:12477-12480.

93. Hayashi H, Abdollah S, Qiu Y, Cai J, Xu YY, Grinnell BW, Richardson MA, Topper JN, Gimbrone MA, Jr., Wrana JL, Falb D: The MAD-related protein Smad7 associates with the TGFbeta receptor and functions as an antagonist of TGFbeta signaling. Cell 1997, 89:1165-1173.

94. Nakao A, Afrakhte M, Moren A, Nakayama T, Christian JL, Heuchel $\mathrm{R}$, Itoh S, Kawabata M, Heldin NE, Heldin CH, ten Dijke P: Identification of Smad7, a TGFbeta-inducible antagonist of TGFbeta signalling. Nature 1997, 389:631-635.

95. Afrakhte M, Moren A, Jossan S, Itoh S, Sampath K, Westermark $\mathrm{B}$, Heldin $\mathrm{CH}$, Heldin NE, ten Dijke P: Induction of inhibitory Smad6 and Smad7 mRNA by TGF-beta family members. Biochem Biophys Res Commun 1998, 249:505-511.

96. Ishisaki A, Yamato $K$, Nakao A, Nonaka $K$, Ohguchi M, ten Dijke $P$, Nishihara T: Smad7 is an activin-inducible inhibitor of activininduced growth arrest and apoptosis in mouse B cells. J Biol Chem 1998, 273:24293-24296.

\section{Correspondence}

Harold L Moses, Vanderbilt University, 691 Preston Research Building, 2220 Pierce Avenue South, Nashville, TN 37232-6838, USA. Tel: +1 615936 1507; fax: +1 615936 1790; e-mail: hal.moses@vanderbilt.edu 